\title{
Factors influencing the implementation of screening and brief interventions for alcohol use in primary care practices: a systematic review using the COM-B system and Theoretical Domains Framework
}

\author{
Frederico Rosário ${ }^{1,2^{*}}$, Maria Inês Santos ${ }^{3}$, Kathryn Angus $^{4}$, Leo Pas ${ }^{5}$, Cristina Ribeiro ${ }^{1}$ and Niamh Fitzgerald ${ }^{4}$ (I)
}

\begin{abstract}
Background: Alcohol is a leading risk factor contributing to the global burden of disease. Several national and international agencies recommend that screening and brief interventions (SBI) should be routinely delivered in primary care settings to reducing patients' alcohol consumption. However, evidence shows that such activities are seldom implemented in practice. A review of the barriers and facilitators mediating implementation, and how they fit with theoretical understandings of behaviour change, to inform the design of implementation interventions is lacking. This study aimed to conduct a theory-informed review of the factors influencing general practitioners' and primary care nurses' routine delivery of alcohol SBI in adults.

Methods: A systematic literature search was carried out in four electronic databases (Medline, CINAHL, CENTRAL, PsycINFO) using comprehensive search strategies. Both qualitative and quantitative studies were included. Two authors independently abstracted and thematically grouped the data extracted. The barriers and facilitators identified were mapped to the domains of the Capability-Opportunity-Motivation-Behaviour system/Theoretical Domains Framework (TDF).

Results: Eighty-four out of the 258 studies identified met the selection criteria. The majority of the studies reported data on the views of general practitioners $(n=60)$ and used a quantitative design $(n=49)$. A total of 660 data items pertaining to barriers and 253 data items pertaining to facilitators were extracted and thematically grouped into 46 themes. The themes mapped to at least one of the 14 domains of the TDF. The three TDF domains with the highest number of data units coded were 'Environmental Context and Resources' ( $n=158$, e.g. lack of time), 'Beliefs about Capabilities' ( $n=134$, e.g. beliefs about the ability to deliver screening and brief advice and in helping patients to cut down) and 'Skills' ( $n=99$, e.g. lack of training).

(Continued on next page)
\end{abstract}

* Correspondence: fredmbr@gmail.com

${ }^{1}$ Instituto de Medicina Preventiva e Saúde Pública, Faculty of Medicine, Lisbon University, Avenida Professor Egas Moniz, 1649-028 Lisbon, Portugal

${ }^{2}$ Agrupamento de Centros de Saúde Dão Lafões, Av. António José de Almeida - Edíficio MAS, 3514-511 Viseu, Portugal

Full list of author information is available at the end of the article

C C The Author(s). 2021 Open Access This article is licensed under a Creative Commons Attribution 4.0 International License, which permits use, sharing, adaptation, distribution and reproduction in any medium or format, as long as you give appropriate credit to the original author(s) and the source, provide a link to the Creative Commons licence, and indicate if changes were made. The images or other third party material in this article are included in the article's Creative Commons licence, unless indicated otherwise in a credit line to the material. If material is not included in the article's Creative Commons licence and your intended use is not permitted by statutory regulation or exceeds the permitted use, you will need to obtain permission directly from the copyright holder. To view a copy of this licence, visit http://creativecommons.org/licenses/by/4.0/. The Creative Commons Public Domain Dedication waiver (http://creativecommons.org/publicdomain/zero/1.0/) applies to the data made available in this article, unless otherwise stated in a credit line to the data. 
(Continued from previous page)

Conclusions: This study identified a range of potential barriers and facilitators to the implementation of alcohol SBI delivery in primary care and adds to the scarce body of literature that identifies the barriers and facilitators from a theoretical perspective. Given that alcohol SBI is seldom implemented, this review provides researchers with a tool for designing novel theory-oriented interventions to support the implementation of such activity.

Systematic review registration: PROSPERO CRD42016052681

Keywords: Alcohol-induced disorders, Screening, Counselling, Primary health care, Review (publication type), Psychological theory

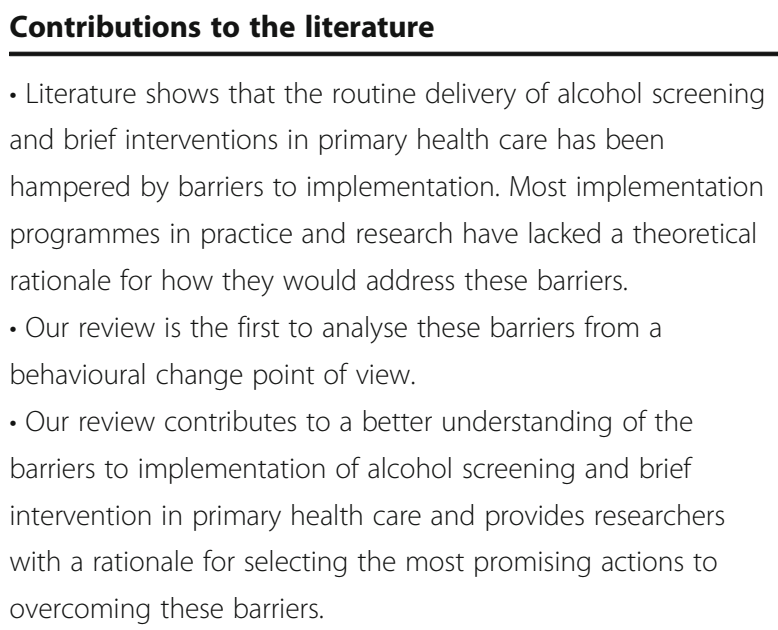

\section{Introduction}

Alcohol misuse is a major risk factor for ill health and death [1], accountable for $5.3 \%$ of all deaths worldwide and $5.1 \%$ of the global burden of disease and injury [2]. The economic impact of alcohol use and related harm alone can reach as much as $3.3 \%$ of the Gross Domestic Product [3]. Even small reductions in alcohol intake can bring about significant health gains [4]. For example, a reduction in the daily average consumption of pure alcohol from 40 to 30 grammes (from 4 to 3 standard drinks) is associated with a $48 \%$ decrease in the risk of oral cancer, and a decrease in the risk of hypertension of $13 \%$ in men and $66 \%$ in women. The World Health Organization recommends the implementation of several high-impact strategies to change drinking behaviour, including the provision of alcohol screening and brief interventions (SBI) in primary health care settings [5].

In the past four decades, randomized controlled trials and meta-analyses have found alcohol SBI in primary care settings to be effective and cost-effective or costsaving [6-13]. Alcohol increases the risk of several physical, mental and social conditions that present frequently in primary care $[3,4]$ and a significant proportion of patients visiting primary care drink least at a hazardous or higher level [14-16]. However, few at-risk drinkers are identified as such and counselled to cut down [17-23]. For example, a recent trial found that, prior to intervention, only $5.9 \%$ of the consulting patients were screened and, of the screen positives, $73.7 \%$ received advice [24]. Therefore, many at-risk drinkers leave their primary care appointment unaware of the risks of their alcohol consumption or how it might be contributing to current ill health. Notwithstanding recent debates questioning SBI effectiveness [25, 26], these represent missed opportunities to increase patients' awareness of alcohol-related risks, a first step towards enabling them to make a more informed choice on whether or not to cut down [4].

Although there is a growing literature on barriers to and facilitators of the implementation of alcohol SBI in routine clinical practice, this information is scattered and provides an unclear representation of the factors affecting primary care providers' systematic engagement with at-risk drinkers. A review by Johnson et al. identified the barriers to and facilitators of the delivery of screening and brief intervention for alcohol misuse [27] but prioritized studies judged to best inform UK practice and focused on several different healthcare settings. Lack of training, support from management and resources, as well as workload pressures were identified as the main barriers to implementation; whilst adequate resources, training and the identification of those at risk without stereotyping were the main facilitators. This review updates the Johnson et al. review, employs a more comprehensive search strategy and has an international focus.

Another gap in the evidence base is the lack of theoretical insights in this area [28]. Knowledge of how identified barriers and facilitators fit with the theoretical understandings of behaviour change can help in selecting the implementation interventions that have a higher chance of bringing about the desired change in practitioner behaviour. Our review is informed by the Capability-Opportunity-Motivation-Behaviour (COM-B) system [29] and Theoretical Domains Framework (TDF) [30] system in that the barriers and facilitators were mapped to the TDF domains which, in turn, fit with the COM-B system. The review aims to identify the 
theoretical concepts underpinning the barriers and facilitators to implementation. Our intention is to provide practical evidence for selecting the best strategies to increase the implementation of alcohol SBI in primary health care.

\section{Objectives}

1. to identify barriers to and facilitators of routine delivery of alcohol screening and brief interventions in adults by general practitioners (GPs) and primary care nurses;

2. to review how the identified barriers and facilitators fit with theoretical understandings of behaviour change using the COM-B system and TDF framework.

\section{Methods}

This review is reported according to the Preferred Reporting Items for Systematic Reviews and MetaAnalysis (PRISMA) statement (see Additional file 1) [31]. The protocol was pre-registered on PROSPERO (CRD42016052681) and published elsewhere [32]. No amendments were introduced to the review protocol.

\section{Information sources and searches}

The following electronic databases were searched by KA, from onset of literature database until May 2016: MEDL INE, CINAHL, Cochrane Central Register of Controlled Trials (CENTRAL) and PsycINFO. The search combined terms for 'Screening and Brief Interventions', 'Alcohol' and 'Primary Health Care' (see Additional file 2).

\section{Eligibility criteria and study selection}

To be included, a study had to:

- report primary data and be published in a peerreviewed scientific journal;

- use a Delphi methodology, focus group, in-depth interview or semi-structured interview design for qualitative studies, or a randomized controlled trial, before-after with no control group, cohort, casecontrol or cross-sectional design for quantitative studies;

- address barriers and facilitators for implementing alcohol SBI reported by GPs or nurses working in primary care general practices (excluding out-ofhours practices or walk-in centres, full definition in protocol [32]);

- be available in full-text copy in English, French, Portuguese or Spanish.

Two reviewers (FR, MIS) independently screened the search results for relevant titles and abstracts. Full-text copies of studies meeting inclusion criteria and of those with unclear eligibility were sought and the screening process repeated by the same two reviewers. Disagreements were discussed and resolved by consensus.

\section{Data extraction and quality assessment}

Data extraction was conducted independently by the two aforementioned reviewers and included the following: first author; publication year; title; country; language; study objective; study design; sample (sampling strategy, type and number of care providers, response/attrition rate); barriers and facilitators; main results; relation with outcomes or process variables in intervention studies.

The methodological quality of each study was independently assessed by two reviewers: half of the studies were appraised by FR and LP, the other half by FR and MIS. Disagreements were resolved through consensus. Quantitative studies were appraised with the NIH National Heart, Lung, and Blood Institute tools [33] and qualitative studies with the critical appraisal skills programme (CASP) qualitative research checklist [34]. The quality of the studies was further appraised as recommended by the Cochrane Collaboration Qualitative Methods Group [35]. Inclusion of studies was not influenced by methodological quality. The quality rating for each study was allocated in line with the guidance in the relevant tool.

\section{Data synthesis}

The data items extracted (i.e. barriers and facilitators, defined as factors that decrease (barriers) or increase (facilitators) the probability of the implementation of the intervention by general practitioners/family physicians or nurses working in primary care practices) were independently extracted by two reviewers (FR, MIS) into a Microsoft Excel sheet. Next, data were grouped thematically: the aforementioned reviewers read and re-read the data items, grouping similar/related items into iteratively developed themes. Each theme was analysed and mapped to the capability, opportunity and motivation components of the COM-B system and the 14 TDF domains, all of which fell into one of these three components. To ensure the theme mapped to the TDF domain, we further checked that the extracted data within each theme fitted with the domain content (i.e. the component constructs in each TDF domain); to remain mapped to the TDF domain, themes had to have at least one data item linked to a component construct. TDF domains were mapped to COM-B components as defined by Cane and colleagues [30]. Disagreements between the reviewers were resolved through consensus. The results are tabulated and a narrative synthesis of the findings is provided, structured around the themes of barriers and facilitators, the professional group and the components 
and domains of the COM-B system and TDF framework.

\section{Results}

\section{Study selection}

The search strategy found 12,436 potentially relevant references (Fig. 1).

After duplicate removal, 8,986 unique references proceeded to abstract screening, from which 272 references were selected for full-text examination. We were unable to obtain full-text copies of 14 references (Additional file 3 ). Of the 258 remaining references, 174 with full-text were excluded (Additional file 4). Eighty-four studies published between 1982 and 2016 satisfied our criteria $[16,20,23,36-116]$ (Table 1). Of the studies included, 76 were single-site studies, mainly from Europe $(n=47)$, North America $(n=12)$ and Oceania $(n=12)$. Seventynine references were published in English, 3 in Portuguese and 2 in Spanish. Forty-nine studies were quantitative, mostly using a cross-sectional design; 30 were qualitative, mainly using focus groups and/or semistructured interviews; the remaining 5 used a mixedmethods approach. Sixty studies reported data on GPs, 9 on nurses and 15 on both.

\section{Methodological quality}

We found considerable variation in the quality of the studies retained (Table 1). Of the 33 qualitative studies, 19 were considered to be good-, 12 fair- and 2 poorquality studies [33-35]. Of the 51 quantitative studies, 18 were considered to be good-, 23 fair- and 10 poorquality studies [33-35].

\section{Summary of findings}

A total of 660 data items (descriptions or reports) pertaining to barriers were extracted. A total of 46 themes were identified from these data items (Table 2).

The most commonly reported barrier-related themes were related to 'beliefs about their ability to deliver SBI and to help patients to cut down' ( $n=62$ data units),

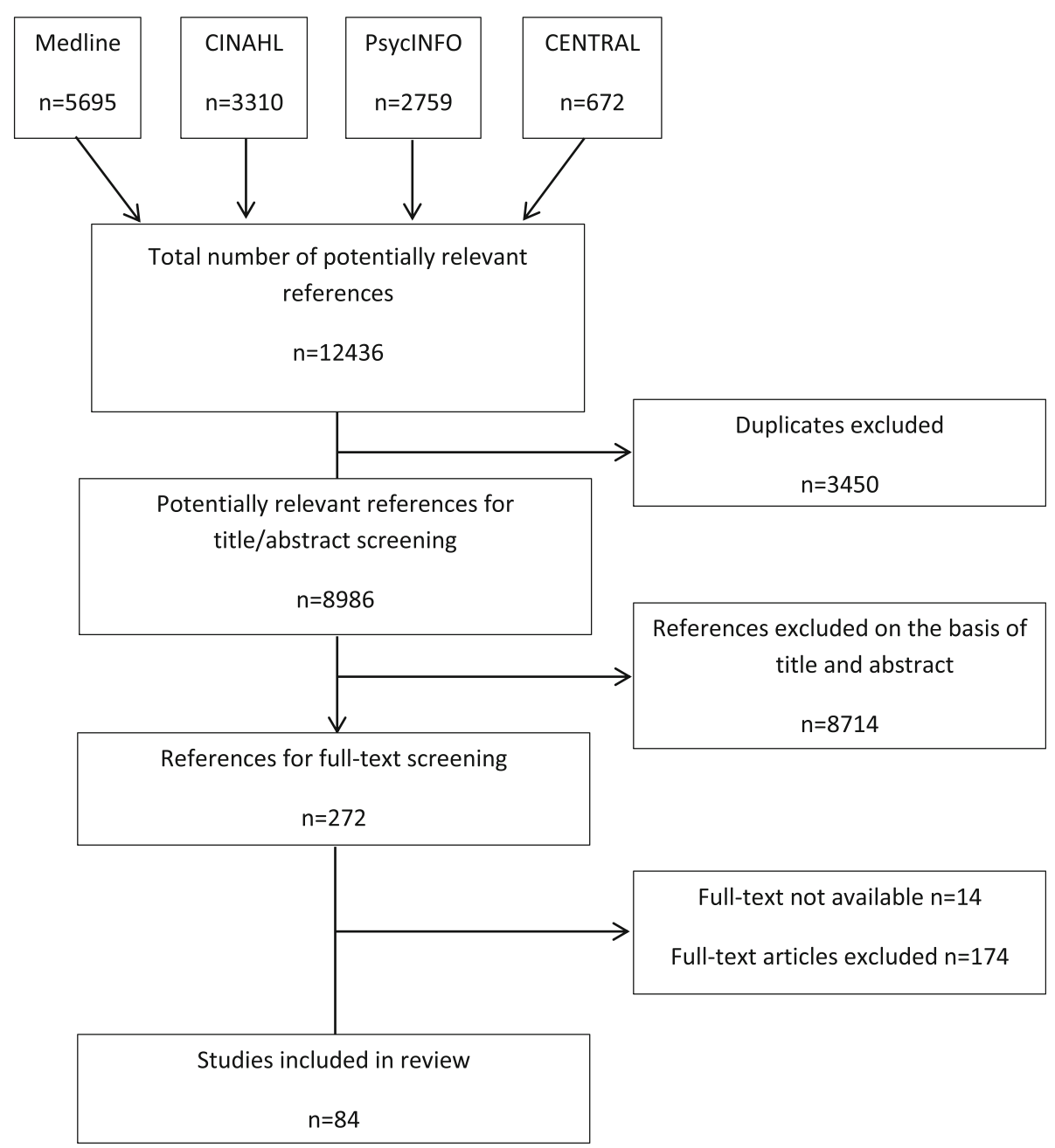

Fig. 1 Flow diagram of screening process 
Table 1 Characteristics of included studies

\begin{tabular}{|c|c|c|c|c|c|c|c|}
\hline \multirow[t]{2}{*}{ First author } & \multirow[t]{2}{*}{ Year } & \multirow[t]{2}{*}{ Country } & \multirow[t]{2}{*}{ Language } & \multirow[t]{2}{*}{ Study design } & \multicolumn{2}{|c|}{$\begin{array}{l}\text { Study sample } \\
(n)\end{array}$} & \multirow[t]{2}{*}{$\begin{array}{l}\text { Methodological } \\
\text { quality }\end{array}$} \\
\hline & & & & & GP & Nurse & \\
\hline Aalto [36] & 2001 & Finland & English & Cross-sectional & 84 & 167 & Good \\
\hline Aalto [38] & 2003 & Finland & English & Cross-sectional & 64 & & Good \\
\hline Aalto [37] & $2003 a$ & Finland & English & Focus group & 18 & 19 & Good \\
\hline Abidi [39] & 2016 & Netherlands & English & Delphi & 37 & & Good \\
\hline $\begin{array}{l}\text { Abouyanni } \\
{[40]}\end{array}$ & 2000 & Australia & English & Cross-sectional & 416 & & Poor \\
\hline Aira [41] & 2003 & Finland & English & $\begin{array}{l}\text { Semi-structured } \\
\text { interviews }\end{array}$ & 35 & & Good \\
\hline Aira [42] & 2004 & Finland & English & $\begin{array}{l}\text { Semi-structured } \\
\text { interviews }\end{array}$ & 35 & & Good \\
\hline Ampt [43] & 2009 & Australia & English & $\begin{array}{l}\text { Semi-structured } \\
\text { interviews }\end{array}$ & 15 & 1 & Good \\
\hline Anderson [44] & 1985 & UK & English & Cross-sectional & 312 & & Good \\
\hline Anderson [46] & 2003 & $\begin{array}{l}\text { Australia, Belgium, Canada, France, Italy, New } \\
\text { Zealand, Norway, Portugal, UK }\end{array}$ & English & Cross-sectional & 1300 & & Good \\
\hline Anderson [45] & 2004 & Australia, Belgium, Spain, UK & English & RCT & 277 & & Good \\
\hline Anderson [47] & 2014 & $\begin{array}{l}\text { Czech Republic, Italy, Netherlands, Poland, } \\
\text { Portugal, Spain, Slovenia, UK }\end{array}$ & English & Cross-sectional & 2345 & & Fair \\
\hline $\begin{array}{l}\text { Arborelius } \\
\text { [48] }\end{array}$ & 1995 & Sweden & English & Structured interviews & 13 & & Fair \\
\hline Beich [49] & 2002 & Denmark & English & $\begin{array}{l}\text { Focus groups } \\
\text { Individual interviews }\end{array}$ & 24 & & Fair \\
\hline Bendtsen [50] & 2015 & Netherlands, Poland, Spain, Sweden, UK & English & Cohort & 409 & 282 & Fair \\
\hline Berner [51] & 2007 & Germany & English & Cross-sectional & 58 & & Fair \\
\hline Brennan [52] & 2013 & Australia & English & Cross-sectional & 15 & & Poor \\
\hline Brotons [53] & 2005 & $\begin{array}{l}\text { Croatia, Estonia, Georgia, Greece, Ireland, Malta, } \\
\text { Poland, Slovakia, Slovenia, Spain, Sweden }\end{array}$ & English & Cross-sectional & 2082 & & Poor \\
\hline Carlfjord [54] & 2012 & Sweden & English & Focus groups & 9 & 12 & Good \\
\hline Casswell [55] & 1982 & New Zealand & English & Cross-sectional & 431 & & Fair \\
\hline Charrel [56] & 2010 & France & English & Cross-sectional & 300 & & Fair \\
\hline Clement [57] & 1986 & UK & English & Cross-sectional & 71 & & Good \\
\hline Clifford [58] & 2011 & Australia & English & $\begin{array}{l}\text { Pre-post training surveys } \\
\text { Focus groups }\end{array}$ & 3 & 3 & Good \\
\hline Deehan [60] & 1997 & UK & English & Cross-sectional & 81 & & Fair \\
\hline Deehan [61] & 1998 & UK & English & Cross-sectional & 2377 & & Poor \\
\hline Deehan [59] & 1999 & UK & English & Cross-sectional & 264 & 196 & Fair \\
\hline Farmer [62] & 2001 & UK & English & $\begin{array}{l}\text { Semi-structured } \\
\text { interviews } \\
\text { Cross-sectional }\end{array}$ & 50 & & Poor \\
\hline Ferguson [63] & 2003 & USA & English & Cross-sectional & 40 & & Poor \\
\hline $\begin{array}{l}\text { Fernández } \\
\text { [64] }\end{array}$ & 1999 & Spain & Spanish & Cross-sectional & 227 & & Fair \\
\hline $\begin{array}{l}\text { Friedmann } \\
{[65]}\end{array}$ & 2000 & USA & English & Cross-sectional & 243 & & Fair \\
\hline Fucito [66] & 2003 & Australia & English & Cross-sectional & 110 & & Good \\
\hline Geirsson [20] & 2005 & Sweden & English & Cross-sectional & 68 & 193 & Good \\
\hline $\begin{array}{l}\text { Gurugama } \\
{[67]}\end{array}$ & 2003 & Sri Lanka & English & Cross-sectional & 105 & & Good \\
\hline
\end{tabular}


Table 1 Characteristics of included studies (Continued)

\begin{tabular}{|c|c|c|c|c|c|c|c|}
\hline \multirow[t]{2}{*}{ First author } & \multirow[t]{2}{*}{ Year } & \multirow[t]{2}{*}{ Country } & \multirow[t]{2}{*}{ Language } & \multirow[t]{2}{*}{ Study design } & \multicolumn{2}{|c|}{$\begin{array}{l}\text { Study sample } \\
\text { (n) }\end{array}$} & \multirow[t]{2}{*}{$\begin{array}{l}\text { Methodological } \\
\text { quality }\end{array}$} \\
\hline & & & & & GP & Nurse & \\
\hline Haley [68] & 2000 & Canada & English & Cross-sectional & 805 & & Fair \\
\hline Harris [69] & 2005 & Australia & English & $\begin{array}{l}\text { Pre-post questionnaire } \\
\text { with no control group }\end{array}$ & 21 & & Poor \\
\hline $\begin{array}{l}\text { Holmqvist } \\
\text { [70] }\end{array}$ & 2008 & Sweden & English & Cross-sectional & 1790 & 2549 & Good \\
\hline $\begin{array}{l}\text { Hutchings } \\
{[71]}\end{array}$ & 2006 & UK & English & Focus groups & 18 & 15 & Good \\
\hline $\begin{array}{l}\text { Johansson } \\
\text { [73] }\end{array}$ & 2002 & Sweden & English & Cross-sectional & 65 & 141 & Good \\
\hline $\begin{array}{l}\text { Johansson } \\
\text { [72] }\end{array}$ & 2005 & Sweden & English & Focus groups & & 26 & Poor \\
\hline $\begin{array}{l}\text { Johansson } \\
{[74]}\end{array}$ & $2005 a$ & Sweden & English & Focus groups & 13 & & Good \\
\hline $\begin{array}{l}\text { Kaariainen } \\
{[75]}\end{array}$ & 2001 & Finland & English & Cross-sectional & $\mathrm{GP}+$ & nurse $=69$ & Fair \\
\hline Kaner [78] & 1999 & UK & English & Cross-sectional & 279 & & Good \\
\hline Kaner [79] & 2001 & $\begin{array}{l}\text { Australia, Belgium, Bulgaria, Canada, France, } \\
\text { Hungary, Italy, New Zealand, Norway, Poland, } \\
\text { Portugal, Thailand, UK }\end{array}$ & English & Cross-sectional & 2139 & & Good \\
\hline Kaner [76] & 2003 & UK & English & Cluster RCT & & $\begin{array}{l}212 \\
\text { general } \\
\text { practices }\end{array}$ & Fair \\
\hline Kaner [77] & 2006 & UK & English & Interviews & 29 & & Good \\
\hline Kersnik [80] & 2009 & Slovenia & English & Focus groups & 32 & & Good \\
\hline Keurhorst [81] & 2014 & Netherlands & English & Cluster RCT & 112 & & Fair \\
\hline Kolsek [82] & 2008 & $\begin{array}{l}\text { Belgium, Bulgaria, Hungary, Italy, Latvia, } \\
\text { Russia, Slovenia }\end{array}$ & English & $\begin{array}{l}\text { Delphi } \\
\text { Focus groups }\end{array}$ & $\mathrm{nr}$ & $\mathrm{nr}$ & Fair \\
\hline Koopman [83] & 2008 & South Africa & English & Cross-sectional & 50 & & Fair \\
\hline Lacey [84] & 2009 & UK & English & $\begin{array}{l}\text { Focus groups } \\
\text { Semi-structured } \\
\text { interviews } \\
\text { Cross-sectional }\end{array}$ & & $\mathrm{nr}$ & Fair \\
\hline Lambe [85] & 2008 & UK & English & $\begin{array}{l}\text { Cross-sectional } \\
\text { Focus groups }\end{array}$ & & 53 & Good \\
\hline Lid [86] & 2012 & Norway & English & Focus groups & 13 & & Fair \\
\hline Lid [87] & 2015 & Norway & English & Focus groups & 19 & & Good \\
\hline Linke [88] & 2005 & UK & English & Focus groups & 10 & & Fair \\
\hline Lock [89] & 2002 & UK & English & $\begin{array}{l}\text { Semi-structured } \\
\text { interviews }\end{array}$ & & 24 & Good \\
\hline Maheux [90] & 1999 & Canada & English & Cross-sectional & 805 & & Fair \\
\hline May [91] & 2006 & UK & English & $\begin{array}{l}\text { Semi-structured } \\
\text { interviews }\end{array}$ & 43 & 1 & Good \\
\hline McAvoy [92] & 2001 & $\begin{array}{l}\text { Australia, Canada, Denmark, France, Hungary, } \\
\text { Italy, New Zealand, Norway, Poland, Russia }\end{array}$ & English & $\begin{array}{l}\text { Semi-structured } \\
\text { interviews }\end{array}$ & 126 & & Fair \\
\hline Miller [93] & 2006 & USA & English & Focus groups & $\mathrm{nr}$ & $\mathrm{nr}$ & Good \\
\hline Miner [94] & 1990 & Spain & Spanish & Cross-sectional & 83 & & Fair \\
\hline Mistral [95] & 2001 & UK & English & $\begin{array}{l}\text { Cross-sectional } \\
\text { Semi-structured } \\
\text { interviews }\end{array}$ & 103 & & Poor \\
\hline Moretti-Pires & 2011 & Brazil & Portuguese & Focus groups & & 12 & Fair \\
\hline
\end{tabular}


Table 1 Characteristics of included studies (Continued)

\begin{tabular}{|c|c|c|c|c|c|c|c|}
\hline \multirow[t]{2}{*}{ First author } & \multirow[t]{2}{*}{ Year } & \multirow[t]{2}{*}{ Country } & \multirow[t]{2}{*}{ Language } & \multirow[t]{2}{*}{ Study design } & \multicolumn{2}{|c|}{$\begin{array}{l}\text { Study sample } \\
\text { (n) }\end{array}$} & \multirow[t]{2}{*}{$\begin{array}{l}\text { Methodological } \\
\text { quality }\end{array}$} \\
\hline & & & & & GP & Nurse & \\
\hline [96] & & & & $\begin{array}{l}\text { Semi-structured } \\
\text { interviews }\end{array}$ & & & \\
\hline Mules [97] & 2012 & New Zealand & English & $\begin{array}{l}\text { Semi-structured } \\
\text { interviews }\end{array}$ & 19 & & Fair \\
\hline Nevin [98] & 2002 & Canada & English & Cross-sectional & 75 & & Fair \\
\hline Nygaard [100] & 2010 & Norway & English & Cross-sectional & 901 & & Good \\
\hline Nygaard [99] & 2011 & Norway & English & Focus groups & 40 & & Good \\
\hline Owens [101] & 2000 & UK & English & Cross-sectional & & 101 & Fair \\
\hline Payne [102] & 2005 & Australia & English & Cross-sectional & 170 & & Fair \\
\hline $\begin{array}{l}\text { Poplas Susic } \\
\text { [103] }\end{array}$ & 2010 & Slovenia & English & Focus groups & 32 & & Good \\
\hline Proude [104] & 2006 & Australia & English & $\begin{array}{l}\text { Pre-post questionnaire } \\
\text { with no control group }\end{array}$ & 300 & & Poor \\
\hline Rapley [105] & 2006 & UK & English & $\begin{array}{l}\text { Semi-structured } \\
\text { interviews }\end{array}$ & 43 & & Good \\
\hline Ribeiro [16] & 2011 & Portugal & Portuguese & Cross-sectional & 188 & & Fair \\
\hline $\begin{array}{l}\text { Richmond } \\
\text { [106] }\end{array}$ & 1998 & Australia & English & $\begin{array}{l}\text { Post-intervention } \\
\text { questionnaire with no } \\
\text { control group }\end{array}$ & 272 & & Poor \\
\hline Roche [107] & 1991 & Australia & English & Focus groups & 44 & & Fair \\
\hline Rush [108] & 1994 & Canada & English & Cross-sectional & 1235 & & Good \\
\hline Rush [109] & 1995 & Canada & English & $\begin{array}{l}\text { Focus groups } \\
\text { Semi-structured } \\
\text { interviews }\end{array}$ & 12 & & Good \\
\hline Segnan [110] & 1992 & Italy & English & Cross-sectional & 209 & & Fair \\
\hline Sharp [111] & 2011 & USA & English & Cross-sectional & 101 & & Good \\
\hline $\begin{array}{l}\text { Slaunwhite } \\
\text { [112] }\end{array}$ & 2015 & Canada & English & Cross-sectional & 67 & & Poor \\
\hline Souza [113] & 2012 & Brazil & Portuguese & $\begin{array}{l}\text { Semi-structured } \\
\text { interviews }\end{array}$ & & 8 & Fair \\
\hline Van Zyl [114] & 2013 & South Africa & English & Cross-sectional & 77 & & Fair \\
\hline $\begin{array}{l}\text { Vandermause } \\
\text { [115] }\end{array}$ & 2007 & USA & English & In-depth interviews & & 23 & Fair \\
\hline Vinson [116] & 2004 & USA & English & Cluster RCT & 44 & & Fair \\
\hline Wilson [23] & 2011 & UK & English & Cross-sectional & 282 & & Good \\
\hline
\end{tabular}

$n r$ Not reported

'alcohol-related knowledge' ( $n=58$ data units), and 'time' ( $n=50$ data units). A total of 253 data items pertaining to facilitators were extracted. All facilitator items related to or addressed one of the 46 barrier themes. Together, the facilitator items mapped onto 22 of the 46 themes. The most commonly reported facilitator-related themes were related to 'support' ( $n=57$ data units), 'training' ( $n=25$ data units) and 'difficult task' ( $n=24$ data units).

TDF domains are numbered as originally designated [30]. All 46 identified themes are mapped to at least one of the three components of the COM-B system and to at least one of the 14 domains of the TDF (Table 2). Additional files 5 and 6 provide a complete description of the barriers and facilitators extracted.

\section{Capability (COM-B component 1 )}

Thirteen themes relate to the capability component of the COM-B system, which includes four TDF domains (Knowledge; Skills; Memory, Attention and Decision Processes; Behavioural regulation). These 13 themes emerged from 68 studies from 26 countries (Table 3). Most studies $(n=40)$ were quantitative in design and reported data mainly from GPs $(n=49)$. 


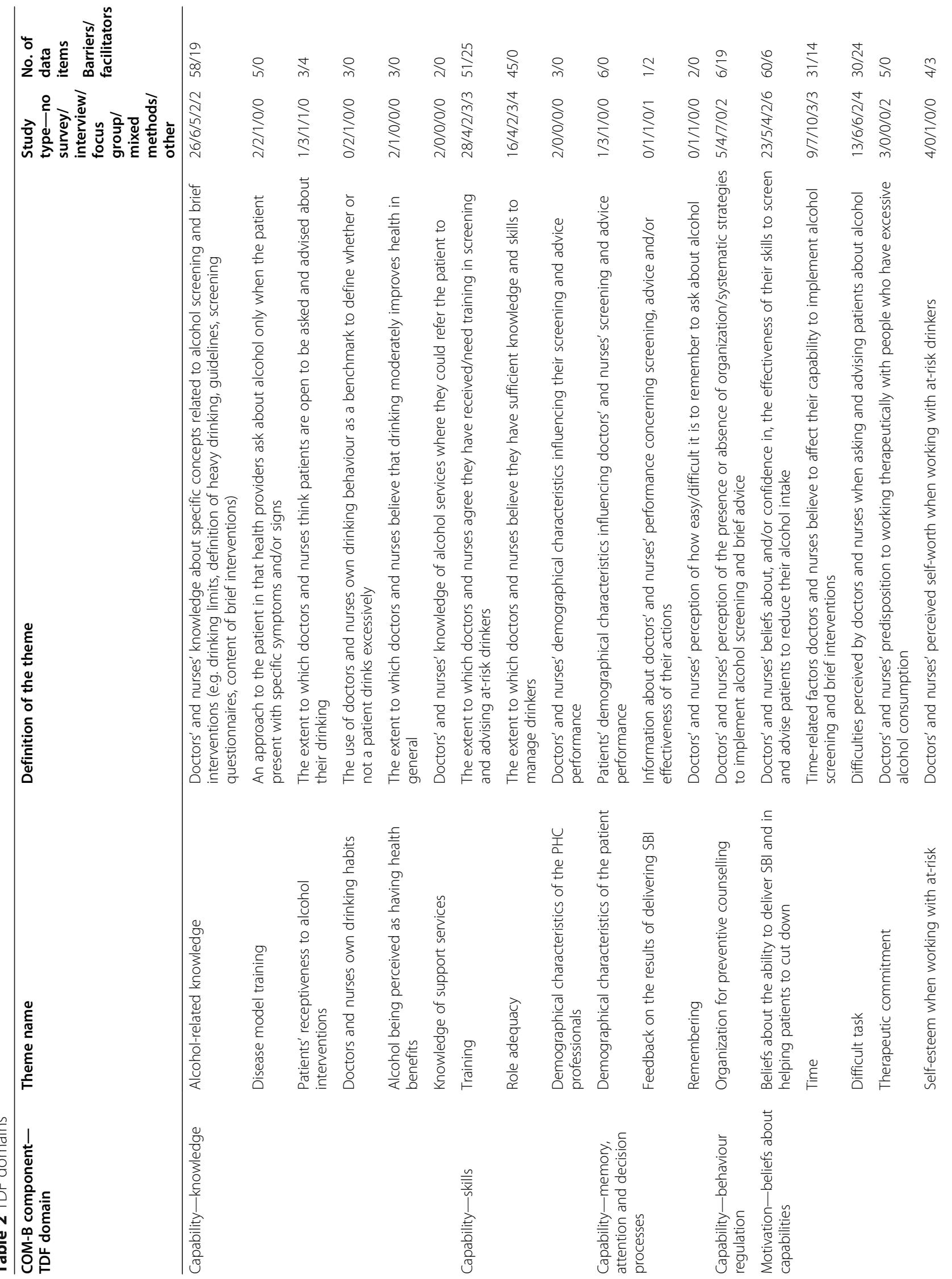




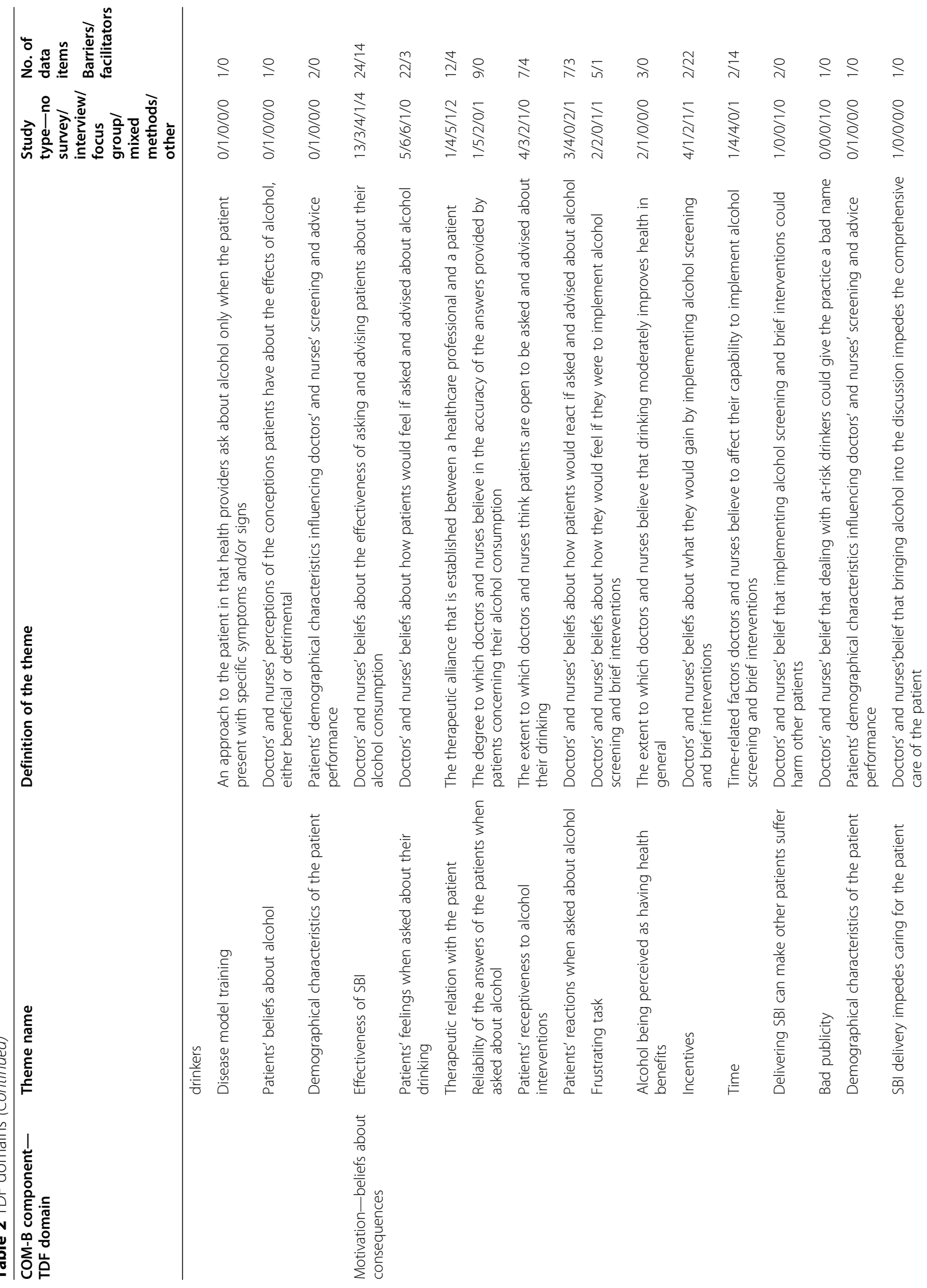




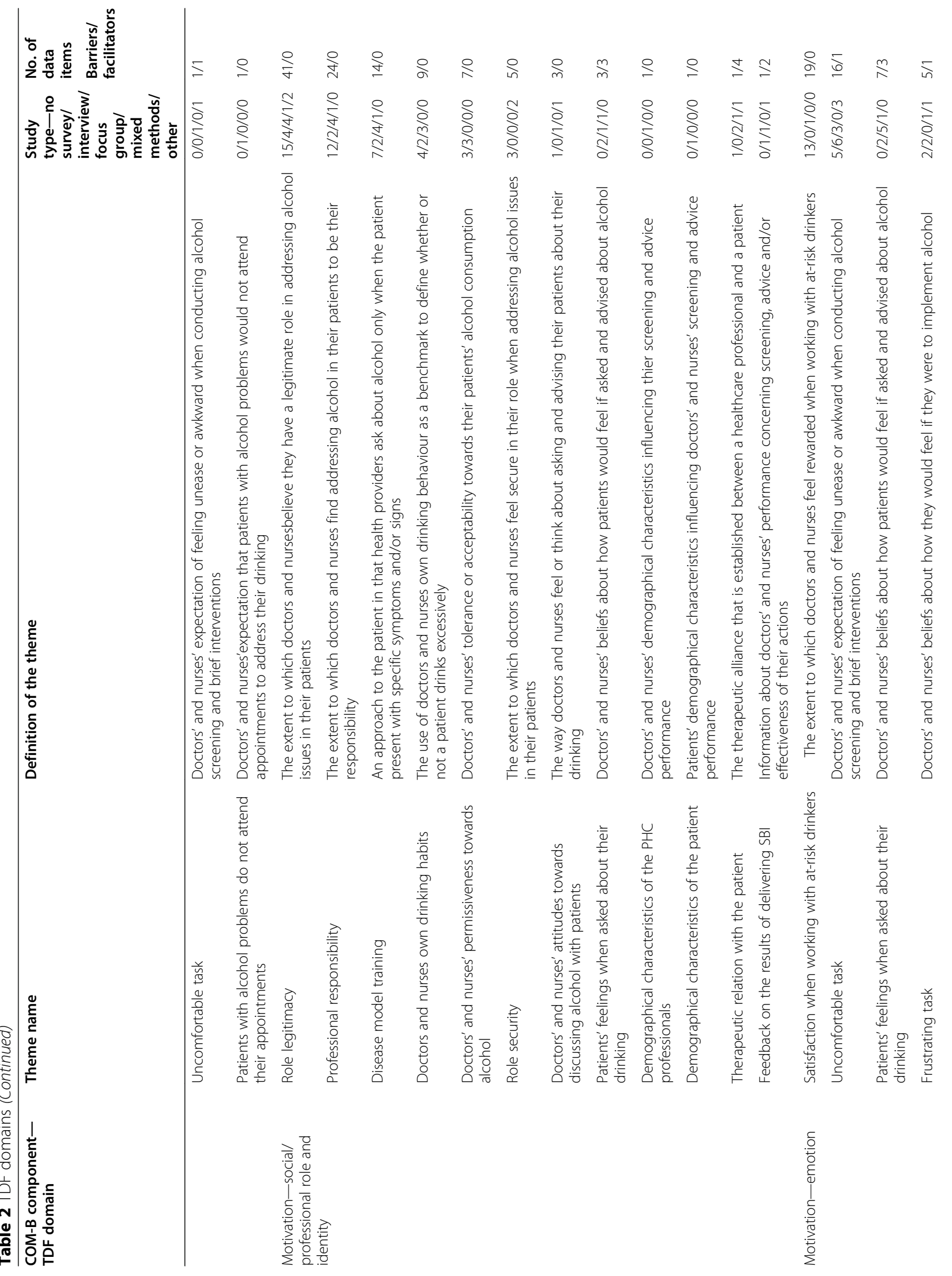




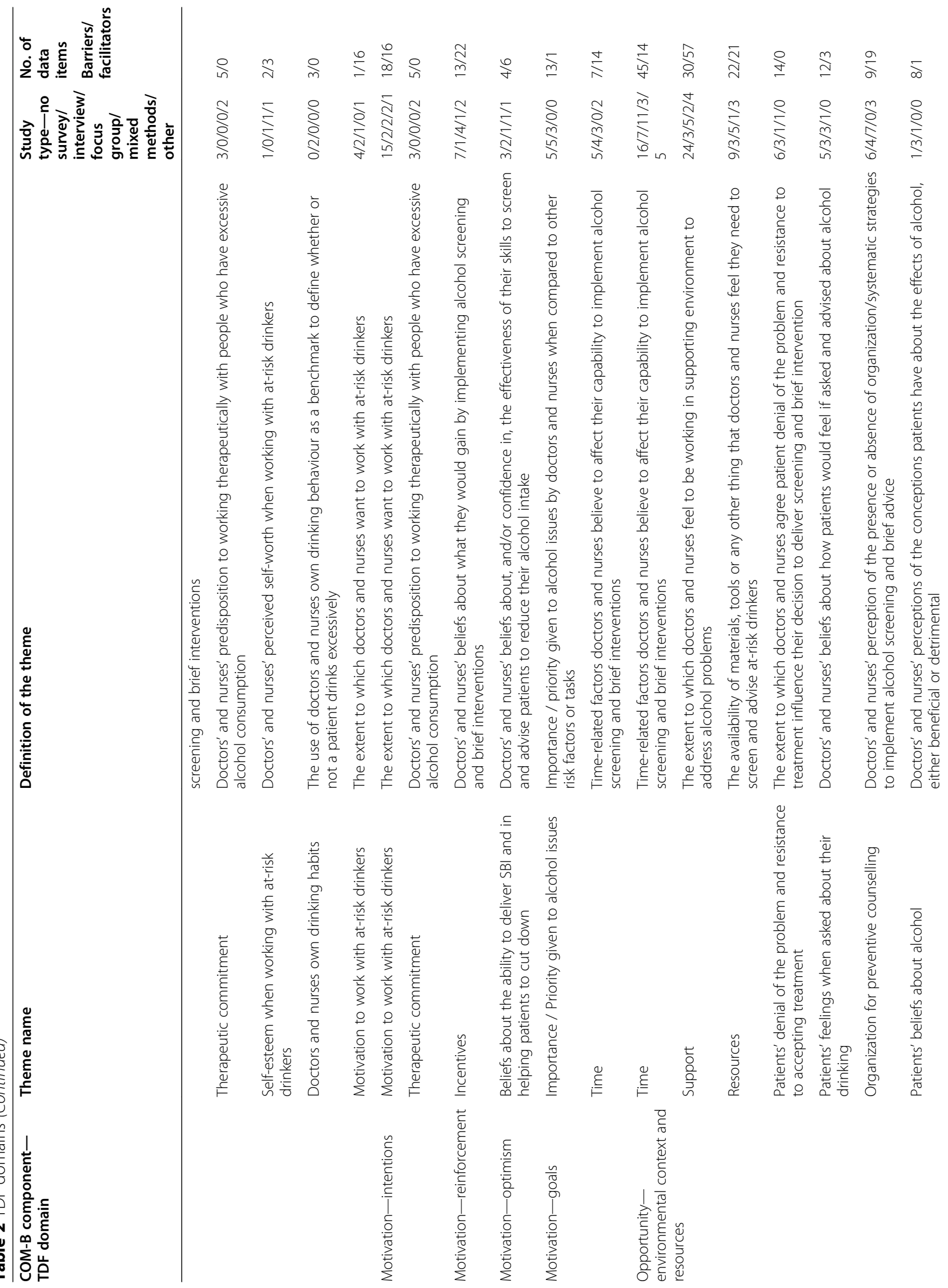




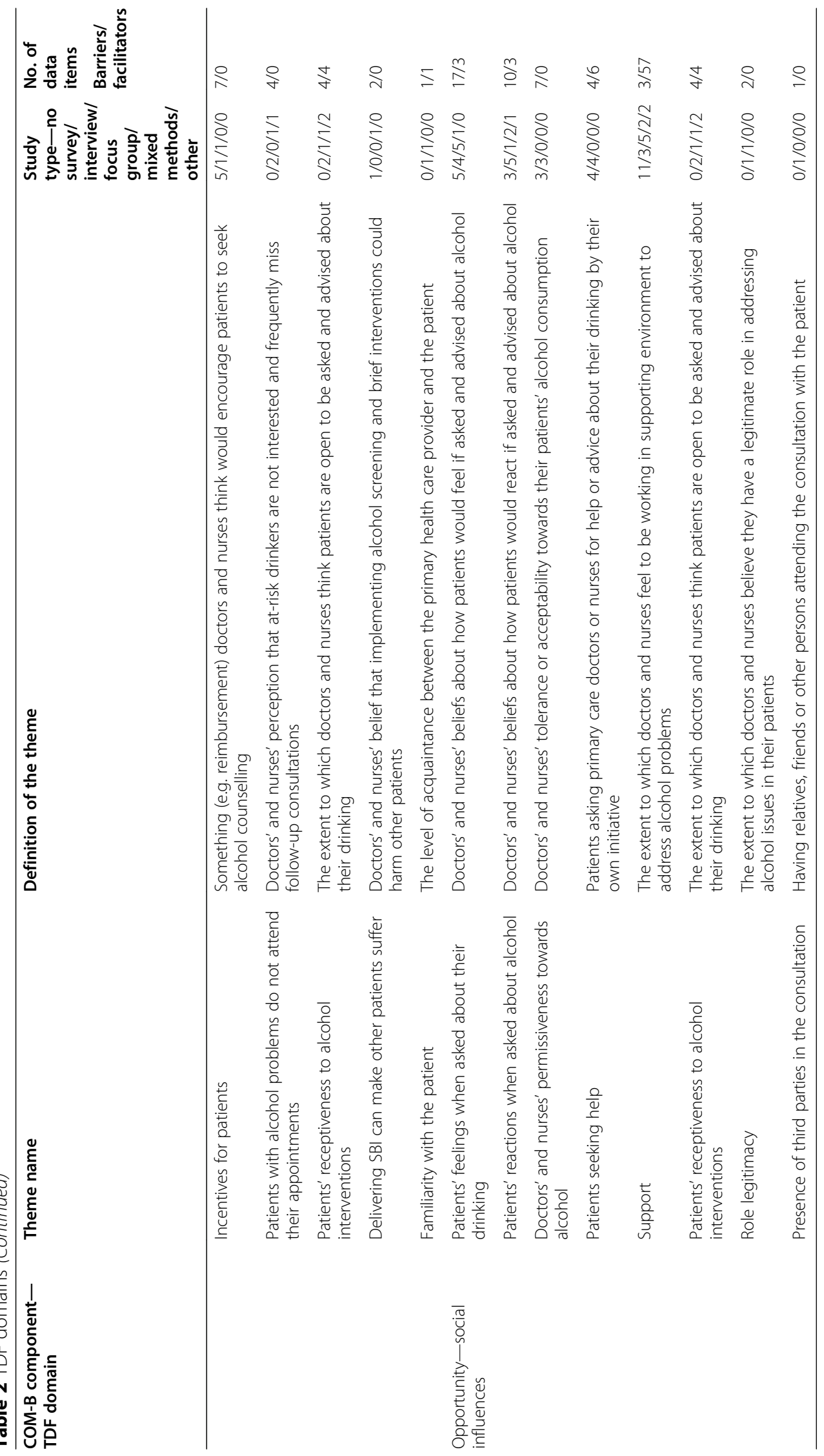


Table 3 Themes coded to each of the TDF domains within the capability component of the COM-B system

\begin{tabular}{|c|c|c|c|c|}
\hline TDF & Theme & Countries & References on barriers & $\begin{array}{l}\text { References on } \\
\text { facilitators }\end{array}$ \\
\hline \multirow[t]{6}{*}{ Knowledge } & $\begin{array}{l}\text { Alcohol-related } \\
\text { knowledge }\end{array}$ & $\begin{array}{l}\text { UK(8); Finland(6); Sweden(4); Multicountry(3); } \\
\text { Norway(3); Australia(2); New Zealand(2); South } \\
\text { Africa(2); Spain(2); USA(2); Brazil(1); Canada(1); } \\
\text { France(1); Netherlands(1); Portugal(1); Slovenia(1); } \\
\text { Sri Lanka(1) }\end{array}$ & $\begin{array}{l}{[16,20,23,36-38,41,42,47,52,56,57,62} \\
64-67,70,73-75,78,83,84,87,89,92,94 \\
96,97,99,101,103,105,108,111,114]\end{array}$ & $\begin{array}{l}{[39,55,70,73,} \\
79,100]\end{array}$ \\
\hline & $\begin{array}{l}\text { Disease model } \\
\text { training }\end{array}$ & Finland(3); Sweden(1); UK(1) & {$[38,41,42,61,74]$} & \\
\hline & $\begin{array}{l}\text { Doctors and } \\
\text { nurses own } \\
\text { drinking habits }\end{array}$ & UK(2); Norway(1) & {$[77,87,89]$} & \\
\hline & $\begin{array}{l}\text { Alcohol being } \\
\text { perceived as } \\
\text { having health } \\
\text { benefits }\end{array}$ & Finland(1); Sweden(1); UK(1) & {$[20,38,42]$} & \\
\hline & $\begin{array}{l}\text { Patients' } \\
\text { receptiveness to } \\
\text { alcohol } \\
\text { interventions }\end{array}$ & $\begin{array}{l}\text { Australia(1); Finland(1); New Zealand(1); Norway(1); } \\
\text { UK(1); USA(1) }\end{array}$ & {$[42,65,105]$} & {$[58,87,97]$} \\
\hline & $\begin{array}{l}\text { Knowledge of } \\
\text { support services }\end{array}$ & Sweden(1); UK(1) & {$[70,101]$} & \\
\hline \multirow[t]{3}{*}{ Skills } & Training & $\begin{array}{l}\text { UK(13); Sweden(5); Multicountry(4); USA(3); } \\
\text { Canada(2); Finland(2); Spain(2); Australia(1); } \\
\text { Brazil(1); Denmark(1); Italy(1); Netherlands(1); New } \\
\text { Zealand(1); Portugal(1); Slovenia(1); South Africa(1); } \\
\text { Sri Lanka(1) }\end{array}$ & $\begin{array}{l}{[16,20,23,36,41,44,46,47,49,52,57,} \\
59-65,67,68,70,76,78,79,83,89,90,92 \\
94-96,99,110,111]\end{array}$ & $\begin{array}{l}{[23,36,39,48} \\
52,55,72,73 \\
78-80,84,92 \\
101]\end{array}$ \\
\hline & Role adequacy & $\begin{array}{l}\text { UK(9); Australia(3); USA(3); Multicountry(2); } \\
\text { Sweden(2); Canada(1); Denmark(1); Finland(1); } \\
\text { New Zealand(1); Norway(1); Portugal(1); } \\
\text { Slovenia(1); South Africa(1); Spain(1); Sri Lanka(1) }\end{array}$ & $\begin{array}{l}{[16,20,23,36,44,47,49,52,57,59,62,64,} \\
65,67,70,78,83,84,87,92,95,97,103- \\
106,108,111,116]\end{array}$ & \\
\hline & $\begin{array}{l}\text { Demographical } \\
\text { characteristics of } \\
\text { the PHC } \\
\text { professionals }\end{array}$ & Germany(1); Norway(1) & {$[51,100]$} & \\
\hline \multirow{3}{*}{$\begin{array}{l}\text { Memory, } \\
\text { attention and } \\
\text { decision } \\
\text { processes }\end{array}$} & $\begin{array}{l}\text { Demographical } \\
\text { characteristics of } \\
\text { the patient }\end{array}$ & Finland(1); Germany(1); Sweden(1); UK(1); USA(1) & {$[41,51,74,105,115]$} & \\
\hline & Remembering & Finland(1); Sweden(1) & {$[41,74]$} & \\
\hline & $\begin{array}{l}\text { Feedback on the } \\
\text { results of } \\
\text { delivering SBI }\end{array}$ & UK(2); Finland(1) & [42] & {$[71,109]$} \\
\hline $\begin{array}{l}\text { Behaviour } \\
\text { regulation }\end{array}$ & $\begin{array}{l}\text { Organization for } \\
\text { preventive } \\
\text { counselling }\end{array}$ & $\begin{array}{l}\text { Sweden(4); UK(4); Slovenia(2); Canada(1); } \\
\text { Finland(1); Multicountry(1); Netherlands(1); New } \\
\text { Zealand(1); Norway(1); South Africa(1); USA(1) }\end{array}$ & {$[47,74,78,83,103,109]$} & $\begin{array}{l}{[39,41,54,70} \\
71,73,76,80 \\
91,93,97,100]\end{array}$ \\
\hline
\end{tabular}

\section{Skills-TDF domain no. 2}

Theme: Training In general, both GPs and nurses reported a lack of training in dealing with alcohol problems. The majority of the GPs thought their medical training was inadequate to address alcohol issues in their patients. Three survey studies from the UK found that only a minority of the GPs and nurses received alcoholspecific training since graduation [59-61]. In 9 survey studies, the majority of the GPs and nurses who received training reported that those programmes lasted less than four hours [20, 23, 44, 46, 47, 70, 76, 78, 79]. Several studies on both GPs and nurses reported availability of educational and training programmes as an important facilitator $[23,36,55,73,78,84]$.

Theme: Role adequacy Mixed evidence was found concerning GPs' and nurses' appraisal of their skills in detecting and advising at-risk drinkers. On the one hand, the majority of the GPs in $9[20,44,47,57,59,62,67$, $83,104]$, and of the nurses in 3 quantitative studies [20, $59,84]$ felt they were not skilled enough to deliver alcohol SBI; on the other hand, the majority of the GPs in $14[16,20,23,36,52,62,64,70,78,83,95,106,108$, 
$111]$, and of the nurses in 2 quantitative studies [36, 70] reported the opposite.

\section{Knowledge-TDF domain no. 1}

Theme: Alcohol-related knowledge A total of 53 data units from 35 studies reporting on barriers were extracted. Most data came from GPs $(n=34)$. Alcoholrelated knowledge included issues of self-reported knowledge of alcohol SBI concepts (e.g. the definition of sensible drinking limits, the content of a brief intervention), and familiarity with guidelines and screening tools. One Spanish study found that $60 \%$ of the GPs had not received alcohol-specific education during medical school [94]. A varying degree of both GPs and nurses in 2 survey studies indicated alcohol-specific education as a facilitator [70, 73].

Theme: Disease model training Four studies (3 qualitative and 1 quantitative) from the Nordic countries mentioned that GPs asked their patients about alcohol only if there was something that made them suspect the patient was a heavy drinker [38, 41, 42, 74]. Notwithstanding, a quantitative study from the UK reported that only $4 \%$ of the GPs agreed that their role was to treat alcohol-related medical complications only [61].

Four other less frequently mentioned themes were linked to this TDF domain (Table 3).

\section{Memory, attention and decision processes-TDF domain no. 10}

Theme: Demographical characteristics of the patient Six pieces of data from 3 qualitative, 1 quantitative and 1 mixed methods studies alluded that both GPs and nurses screening activities were influenced by patients' characteristics $[41,51,74,105,115]$. Older patients and being a female were found to be at lower odds of being detected as problem drinkers, whilst visiting the GP more than 5 times within the last year increased the chances of detection.

Theme: Remembering Asking patients about alcohol was found easy to forget in 2 qualitative studies on GPs from the Nordic countries [41, 74].

Theme: Feedback on the results of delivering SBI One interview study from Finland found that GPs were unaware of whether or not patients they advised reduced their drinking because GPs do not schedule follow-up appointments [42].
Behavioural regulation-TDF domain no. 14

Theme: Organization for preventive counselling Three survey studies showed that 40 to $86 \%$ of the GPs believed general practices are not organized to do preventive counselling [47, 78, 83]. GPs in 3 qualitative studies mentioned that implementation strategies for routine screening of at-risk drinkers were lacking [74, 103, 109]. GPs and nurses often cited improving professional teamwork (e.g. having a practice nurse delivering SBI, having receptionists giving patients screening tools) as a facilitator $[39,41,54,70,71,73,76,80,91,93,97,99]$.

\section{Motivation (COM-B component 2)}

The 33 themes in the motivation component of the COM-B system, which includes eight TDF domains (Social/professional role and identity; Beliefs about capabilities; Optimism; Beliefs about Consequences; Reinforcement; Intentions; Goals; Emotion), emerged from 75 studies from 30 countries (Table 4). The majority of the studies $(n=43)$ were quantitative in design and reported data mainly from GPs $(n=54)$.

\section{Beliefs about capabilities-TDF domain no. 4}

Theme: Beliefs about the ability to deliver SBI and in helping patients to cut down Twenty-three studies reported on how GPs felt about their abilities for screening and advising at-risk drinkers, of which 16 found a majority of GPs believed they were confident in their abilities $[20,36,40,44-47,50,52,59-62,64,65,67,78,81,83$, 104, 106, 108, 111] compared with 1 of 3 studies involving nurses [20, 36, 59]. Notwithstanding, the majority of the GPs in 7 from a total of 11 studies [20, 53, 55, 59$62,65,78,83,108]$, and of the nurses in 2 studies [20, 85], did not feel their advice would have much impact. GPs and nurses reported more training for improving counselling skills $[20,49,78,83]$ and feedback on successful cases [71] as facilitators.

Theme: Time Lack of time was cited as a barrier, mainly by GPs, in 28 studies. Two main sub-themes were identified: having competing demands (e.g. needing to attend patients with multiple health problems); and thinking that alcohol SBI is too time consuming. More time per consultation, more experience in delivering brief interventions and simplifying the screening process (e.g. short and simple screening tools, giving patients self-report questionnaires) are examples of reported facilitators [39, 43, 93, 97].

Six other less frequently mentioned themes were linked to this TDF domain (Table 4). 
Table 4 Themes coded to each of the TDF domains within the motivation component of the COM-B system

\begin{tabular}{|c|c|c|c|c|}
\hline TDF & Theme & Countries & References on barriers & $\begin{array}{l}\text { References } \\
\text { on } \\
\text { facilitators }\end{array}$ \\
\hline \multirow[t]{8}{*}{$\begin{array}{l}\text { Beliefs about } \\
\text { capabilities }\end{array}$} & $\begin{array}{l}\text { Beliefs about the ability } \\
\text { to deliver SBI and in } \\
\text { helping patients to cut } \\
\text { down }\end{array}$ & $\begin{array}{l}\text { UK(11); Australia(5); Multicountry(5); Finland(3); } \\
\text { Sweden(3); USA(3); Canada(2); Denmark(1); New } \\
\text { Zealand(2); Netherlands(1); South Africa(1); Spain(1); } \\
\text { Sri Lanka(1) }\end{array}$ & $\begin{array}{l}{[20,36,37,40,41,44-48,50,52,53} \\
55,59-62,64,65,67,72,75,78,81 \\
84,85,97,101,104-109,111,116]\end{array}$ & $\begin{array}{l}{[48,49,71,78,} \\
100]\end{array}$ \\
\hline & Time & $\begin{array}{l}\text { Sweden(7); Australia(5); UK(5); USA(4); Finland(2); } \\
\text { Norway(2); Canada(1); Denmark(1); Multicountry(1); } \\
\text { Netherlands(1); New Zealand(1); Portugal(1); } \\
\text { Slovenia(1); Sri Lanka(1) }\end{array}$ & $\begin{array}{l}{[16,20,37,41,48,49,52,54,58,62} \\
63,65,67,70,72-74,87,91,92,95 \\
97,99,105-107,109,111]\end{array}$ & $\begin{array}{l}{[39,43,70,71} \\
80,92,93,97]\end{array}$ \\
\hline & Difficult task & $\begin{array}{l}\text { UK(8); Australia(3); Canada(3); Finland(3); Norway(3); } \\
\text { Multicountry(2); Sweden(2); Brazil(1); Denmark(1); } \\
\text { Netherlands(1); New Zealand(1); Portugal(1); South } \\
\text { Africa(1); Sri Lanka(1) }\end{array}$ & $\begin{array}{l}{[16,23,37,41,42,49,54,59-62,67} \\
68,73,78,83,86,90,92,97,99,102 \\
105,107,109,113]\end{array}$ & $\begin{array}{l}{[39,41,58,62} \\
71,86,87,97 \\
99,105,109]\end{array}$ \\
\hline & Therapeutic commitment & Multicountry(4); Netherlands(1) & {$[45-47,50,81]$} & \\
\hline & $\begin{array}{l}\text { Self-esteem when } \\
\text { working with at-risk } \\
\text { drinkers }\end{array}$ & UK(3); Portugal(1); Sweden(1) & {$[16,20,23,78]$} & {$[71]$} \\
\hline & Disease model training & Finland(1) & [41] & \\
\hline & $\begin{array}{l}\text { Patients' misbeliefs about } \\
\text { alcohol }\end{array}$ & $\mathrm{UK}(1)$ & {$[105]$} & \\
\hline & $\begin{array}{l}\text { Demographical } \\
\text { characteristics of the } \\
\text { patient }\end{array}$ & New Zealand(1) & {$[97]$} & \\
\hline \multirow[t]{14}{*}{$\begin{array}{l}\text { Beliefs about } \\
\text { consequences }\end{array}$} & Effectiveness of SBI & $\begin{array}{l}\text { UK(6); Finland(3); Sweden(3); Australia(2); } \\
\text { Multicountry(2); Norway(2); Canada(1); Denmark(1); } \\
\text { Italy(1); Netherlands(1); New Zealand(1); South } \\
\text { Africa(1); Spain(1) }\end{array}$ & $\begin{array}{l}{[20,23,36,38,42,45,49,55,57,64} \\
70,73,78,83,84,86,91,106,107 \\
110]\end{array}$ & $\begin{array}{l}{[23,36,39,47} \\
71,78,84,87 \\
92,109]\end{array}$ \\
\hline & $\begin{array}{l}\text { Patients' feelings when } \\
\text { asked about their } \\
\text { drinking }\end{array}$ & $\begin{array}{l}\text { Norway(3); UK(3); Finland(2); Multicountry(2); } \\
\text { USA(2); Australia(1); Brazil(1); France(1); New } \\
\text { Zealand(1); Slovenia(1); Sweden(1) }\end{array}$ & $\begin{array}{l}{[20,23,41,42,47,56,71,78,84,87} \\
92,93,97,99,103,113,115]\end{array}$ & {$[58,93]$} \\
\hline & $\begin{array}{l}\text { Therapeutic relation with } \\
\text { the patient }\end{array}$ & $\begin{array}{l}\text { Sweden(3); UK(2); Canada(1); Denmark(1); } \\
\text { Finland(1); France(1); New Zealand(1); Norway(1); } \\
\text { Slovenia(1); USA(1) }\end{array}$ & $\begin{array}{l}{[37,48,49,56,72,74,91,97,99} \\
103,109,115]\end{array}$ & {$[49,74,84,99]$} \\
\hline & $\begin{array}{l}\text { Reliability of the answers } \\
\text { of the patients when } \\
\text { asked about alcohol }\end{array}$ & $\begin{array}{l}\text { Finland(2); Denmark(1); Multicountry (1); New } \\
\text { Zealand(1); Norway(1); Sri Lanka(1); Sweden(1); } \\
\text { UK(1) }\end{array}$ & {$[37,42,48,49,67,89,92,97,99]$} & \\
\hline & $\begin{array}{l}\text { Patients' reactions when } \\
\text { asked about alcohol }\end{array}$ & $\begin{array}{l}\text { Sweden(3); UK(3); Australia(1); Denmark(1); } \\
\text { Finland(1); Multicountry(1) }\end{array}$ & {$[70,73,84,89,92,95,102]$} & {$[41,48,49]$} \\
\hline & $\begin{array}{l}\text { Patients' receptiveness to } \\
\text { alcohol interventions }\end{array}$ & $\begin{array}{l}\text { Finland(2); USA(2); Australia(1); New Zealand(1); } \\
\text { Norway(1); Slovenia(1); Sweden(1); UK(1) }\end{array}$ & {$[36,42,63,65,73,103,105]$} & {$[58,87,97]$} \\
\hline & Frustrating task & UK(3); Canada(1); Portugal(1); Sweden(1) & {$[16,57,62,77,109]$} & {$[48]$} \\
\hline & $\begin{array}{l}\text { Alcohol being perceived } \\
\text { as having health benefits }\end{array}$ & Finland(1); Sweden(1); UK(1) & {$[20,42,78]$} & \\
\hline & Incentives & $\begin{array}{l}\text { UK(3); Australia(1); Finland(1); Multicountry(1); } \\
\text { Netherlands(1); Slovenia(1); Sweden(1) }\end{array}$ & {$[95,107]$} & $\begin{array}{l}{[20,23,36,39,} \\
78,80,92]\end{array}$ \\
\hline & Time & $\begin{array}{l}\text { Sweden(2); Australia(1); Finland(1); Multicountry(1); } \\
\text { Netherlands(1); New Zealand(1); Slovenia(1); UK(1); } \\
\text { USA(1) }\end{array}$ & {$[37,48]$} & $\begin{array}{l}{[39,43,70,71} \\
80,92,93,97]\end{array}$ \\
\hline & $\begin{array}{l}\text { Delivering SBI can make } \\
\text { other patients suffer }\end{array}$ & Sweden(1); UK(1) & {$[73,95]$} & \\
\hline & Bad publicity & UK(1) & [95] & \\
\hline & $\begin{array}{l}\text { Demographical } \\
\text { characteristics of the } \\
\text { patient }\end{array}$ & UK(1) & [89] & \\
\hline & $\begin{array}{l}\text { SBI delivery impedes } \\
\text { caring for other patients }\end{array}$ & Finland(1) & {$[38]$} & \\
\hline
\end{tabular}


Table 4 Themes coded to each of the TDF domains within the motivation component of the COM-B system (Continued)

\begin{tabular}{|c|c|c|c|c|}
\hline TDF & Theme & Countries & References on barriers & $\begin{array}{l}\text { References } \\
\text { on } \\
\text { facilitators }\end{array}$ \\
\hline & Uncomfortable task & Australia(1); Netherlands(1) & [107] & [39] \\
\hline & $\begin{array}{l}\text { Patients with alcohol } \\
\text { problems do not attend } \\
\text { their appointments }\end{array}$ & New Zealand(1) & [97] & \\
\hline \multirow{12}{*}{$\begin{array}{l}\text { Social/ } \\
\text { professional } \\
\text { role and } \\
\text { identity }\end{array}$} & Role legitimacy & $\begin{array}{l}\text { UK(7); Finland(5); Sweden(3); Canada(2); New } \\
\text { Zealand(2); Australia(1); Denmark(1); Norway(1); } \\
\text { Portugal(1); Slovenia(1); South Africa(1); Spain(1) }\end{array}$ & $\begin{array}{l}{[16,23,36-38,44,49,52,55,57,62} \\
64,72-75,78,83,89,97,99,102 \\
105,108,109]\end{array}$ & \\
\hline & Professional responsibility & $\begin{array}{l}\text { UK(7); Sweden(3); Finland(2); New Zealand(2); } \\
\text { Australia(1); Multicountry(1); South Africa(1); Sri } \\
\text { Lanka(1); USA(1) }\end{array}$ & $\begin{array}{l}{[23,37,38,47,55,59-62,65,67} \\
72-74,78,83,97,105,107]\end{array}$ & \\
\hline & Disease model training & $\begin{array}{l}\text { UK(4); Sweden(3); Finland(2); Australia(1); } \\
\text { Multicountry(1); Norway(1); South Africa(1); Sri } \\
\text { Lanka(1) }\end{array}$ & $\begin{array}{l}{[23,41,42,47,58,61,67,72-74,78} \\
83,88,99]\end{array}$ & \\
\hline & $\begin{array}{l}\text { Doctors and nurses own } \\
\text { drinking habits }\end{array}$ & $\begin{array}{l}\text { UK(4); Canada(1); Multicountry(1); Norway(1); } \\
\text { Slovenia(1); Sweden(1) }\end{array}$ & {$[23,47,74,77,78,87,89,98,103]$} & \\
\hline & $\begin{array}{l}\text { Doctors' and nurses' } \\
\text { permissiveness towards } \\
\text { alcohol }\end{array}$ & $\begin{array}{l}\text { UK(2); Finland(1); Multicountry(1); Sweden(1); } \\
\text { USA(1) }\end{array}$ & {$[20,23,38,47,89,115]$} & \\
\hline & Role security & Multicountry(4); Netherlands(1) & {$[45-47,50,81]$} & \\
\hline & $\begin{array}{l}\text { Doctors' and nurses' } \\
\text { attitudes towards } \\
\text { discussing alcohol with } \\
\text { patients }\end{array}$ & Finland(2); Denmark(1) & {$[36,37,49]$} & \\
\hline & $\begin{array}{l}\text { Patients' feelings when } \\
\text { asked about their } \\
\text { drinking }\end{array}$ & Finland(2); Australia(1); USA(1) & {$[41,42,93]$} & \\
\hline & $\begin{array}{l}\text { Demographical } \\
\text { characteristics of the PHC } \\
\text { professionals }\end{array}$ & Australia(1); Canada(1) & {$[107,109]$} & \\
\hline & $\begin{array}{l}\text { Demographical } \\
\text { characteristics of the } \\
\text { patient }\end{array}$ & UK(1) & [89] & \\
\hline & $\begin{array}{l}\text { Therapeutic relation with } \\
\text { the patient }\end{array}$ & Denmark(1); Finland(1); Norway(1); Sweden(1); UK(1) & [38] & {$[49,74,84,99]$} \\
\hline & $\begin{array}{l}\text { Feedback on the results } \\
\text { of delivering SBI }\end{array}$ & UK(2); Finland(1) & {$[42]$} & {$[71,109]$} \\
\hline \multirow[t]{8}{*}{ Emotion } & Uncomfortable task & $\begin{array}{l}\text { UK(5); Finland(2); USA(2); Canada(1); France(1); } \\
\text { Multicountry(1); Netherlands(1); New Zealand(1); } \\
\text { Norway(1); South Africa(1); Sweden(1) }\end{array}$ & $\begin{array}{l}{[23,37,41,47,54,56,77,78,83,89} \\
91,97,99,109,115,116]\end{array}$ & {$[39]$} \\
\hline & $\begin{array}{l}\text { Satisfaction when } \\
\text { working with at-risk } \\
\text { drinkers }\end{array}$ & $\begin{array}{l}\text { UK(8); Sweden(2); Canada(1); Portugal(1); Spain(1); } \\
\text { Sri Lanka(1) }\end{array}$ & $\begin{array}{l}{[16,20,23,44,57,59-62,67,73,78,} \\
94,108]\end{array}$ & \\
\hline & $\begin{array}{l}\text { Patients' feelings when } \\
\text { asked about their } \\
\text { drinking }\end{array}$ & $\begin{array}{l}\text { Norway(3); USA(2); Australia(1); New Zealand(1); } \\
\text { UK(1); }\end{array}$ & {$[71,86,87,97,99,115]$} & {$[58,93]$} \\
\hline & Frustrating task & UK(3); Canada(1); Portugal(1); Sweden(1) & {$[16,57,62,77,109]$} & {$[48]$} \\
\hline & Therapeutic commitment & Multicountry(4); Netherlands(1) & {$[45-47,50,81]$} & \\
\hline & $\begin{array}{l}\text { Self-esteem when } \\
\text { working with at-risk } \\
\text { drinkers }\end{array}$ & UK(2); Canada(1) & {$[62,108]$} & [71] \\
\hline & $\begin{array}{l}\text { Doctors and nurses own } \\
\text { drinking habits }\end{array}$ & UK(2) & {$[77,89]$} & \\
\hline & $\begin{array}{l}\text { Motivation to work with } \\
\text { at-risk drinkers }\end{array}$ & $\begin{array}{l}\text { UK(3); Multicountry(1); Netherlands(1); Norway(1); } \\
\text { Sri Lanka(1); Sweden(1) }\end{array}$ & [105] & $\begin{array}{l}{[39,47,48,59} \\
60,67,99]\end{array}$ \\
\hline
\end{tabular}


Table 4 Themes coded to each of the TDF domains within the motivation component of the COM-B system (Continued)

\begin{tabular}{|c|c|c|c|c|}
\hline TDF & Theme & Countries & References on barriers & $\begin{array}{l}\text { References } \\
\text { on } \\
\text { facilitators }\end{array}$ \\
\hline \multirow[t]{2}{*}{ Intentions } & $\begin{array}{l}\text { Motivation to work with } \\
\text { at-risk drinkers }\end{array}$ & $\begin{array}{l}\text { UK(9); Sweden(3); Australia(2); Spain(2); Canada(1); } \\
\text { Multicountry(1); Netherlands(1); Portugal(1); Sri } \\
\text { Lanka(1); USA(1) }\end{array}$ & $\begin{array}{l}{[16,20,23,44,57,62,64-66,78,94,} \\
95,105,107,108]\end{array}$ & $\begin{array}{l}{[39,47,48,59,} \\
60,67,99]\end{array}$ \\
\hline & Therapeutic commitment & Multicountry(4); Netherlands(1) & {$[45-47,50,81]$} & \\
\hline Reinforcement & $\begin{array}{l}\text { Incentives for delivering } \\
\text { SBI }\end{array}$ & $\begin{array}{l}\text { UK(3); Australia(2); Multicountry(2); Slovenia(2); } \\
\text { Finland(1); Netherlands(1); Norway(1); Portugal(1); } \\
\text { South Africa(1); Sweden(1) }\end{array}$ & $\begin{array}{l}{[16,23,47,78,83,92,95,99,103} \\
106,107]\end{array}$ & $\begin{array}{l}{[20,23,36,39,} \\
78,80,92]\end{array}$ \\
\hline \multirow[t]{2}{*}{ Goals } & $\begin{array}{l}\text { Importance/priority given } \\
\text { to alcohol issues }\end{array}$ & $\begin{array}{l}\text { UK(4); Sweden(3); Multicountry(2); Norway(2); } \\
\text { Finland(1); USA(1) }\end{array}$ & $\begin{array}{l}{[20,23,41,47,48,65,71,74,78,88,} \\
92,105]\end{array}$ & [99] \\
\hline & Time & $\begin{array}{l}\text { UK(4); Australia(2); Multicountry(2); Netherlands(1); } \\
\text { New Zealand(1); Slovenia(1); South Africa(1); } \\
\text { Sweden(1); USA(1) }\end{array}$ & {$[23,47,78,83,92,105,106]$} & $\begin{array}{l}{[39,43,70,71} \\
80,92,93,97]\end{array}$ \\
\hline Optimism & $\begin{array}{l}\text { Beliefs about the ability } \\
\text { to deliver SBI and in } \\
\text { helping patients to cut } \\
\text { down }\end{array}$ & $\begin{array}{l}\text { UK(3); Denmark(1), Multicountry(1); New Zealand(1); } \\
\text { Norway(1); Sweden(1) }\end{array}$ & {$[55,62,92]$} & $\begin{array}{l}{[48,49,71,78,} \\
100]\end{array}$ \\
\hline
\end{tabular}

Beliefs about Consequences-TDF domain no. 6

Theme: Effectiveness of SBI Mixed evidence was found concerning whether or not GPs believed in the effectiveness of brief interventions for reducing alcohol consumption. In 4 quantitative and 4 qualitative studies GPs were sceptical that patients would follow their advice $[20,42,47,49,78,83,91,107]$; data from 6 quantitative and 1 qualitative studies point otherwise $[23,64,70,73$, $86,106,110]$. Three studies on nurses found that most believed in the efficacy of brief interventions [70, 73, 84]. More information about the effectiveness of brief interventions [23, 36, 39, 47, 78, 84, 87, 92] and feedback on successful cases $[71,109]$ were identified as implementation facilitators.

Theme: Patients' feelings when asked about their drinking Evidence from several qualitative studies suggest that GPs and nurses might be afraid to offend their patients by asking them about alcohol. This issue was addressed in 5 survey studies among GPs, of which 4 found a majority of GPs did not believe patients would resent being asked [20, 23, 47, 56, 78]. Increasing experience with screening and normalizing alcohol questions were reported as facilitators [93].

Fourteen other less frequently mentioned themes were linked to this TDF domain (Table 4).

\section{Social/professional role and identity-TDF domain no. 3}

Theme: Role legitimacy In general, the majority of both GPs and nurses agreed that identifying and providing alcohol-related advice is a natural part of their job. Nearly all GPs in 3 studies from the UK and Canada believed they have the right to ask patients about alcohol and that their patients share this view $[57,62,108]$.

Theme: Professional responsibility Believing that preventing alcohol problems is a GP responsibility was found to vary substantially from country to country. On the one hand, the majority of the GPs in 1 multicountry and 1 South African studies reported that these problems were not their responsibility [47, 67]; on the other hand, the majority of the GPs in 2 studies from the UK and 1 study from the USA thought the opposite $[23,65,78]$.

Theme: Disease model training A varying number of GPs agreed to have disease model training and that they do not think about prevention. Data, mainly from qualitative studies, suggested that GPs and nurses do not screen systematically for alcohol but only when they suspected heavy consumption, or when the patient's complaint was likely to be alcoholrelated [41, 42, 58, 67, 72-74, 88].

Nine other less frequently mentioned themes were linked to this TDF domain (Table 4).

\section{Emotion-TDF domain no. 13}

Theme: Uncomfortable task Several GPs and nurses expressed feeling uneasy when asking patients about their drinking. In 10 qualitative studies, primary health care (PHC) providers considered asking about alcohol a delicate task because alcohol is viewed as a sensitive issue, making them feel uncomfortable [37, 41, 54, 77, 89, 91, 97, 99, 109, 115]. Notwithstanding, the majority of the GPs in 4 from a total of 6 quantitative studies reported feeling comfortable asking about alcohol [23, 47, 
56, 78, 83, 116]. Destigmatizing problematic alcohol use was identified as a facilitator in 1 qualitative study [39].

Theme: Satisfaction when working with at-risk drinkers With the notable exception of 1 study on GPs from Sri Lanka [67], the majority of the GPs in the remaining 13 studies addressing this issue ( 8 from the UK), and of the nurses in 3 studies ( 2 from Sweden and 1 from the UK) reported feeling unsatisfied advising patients to cut down [16, 20, 23, 44, 57, 59-62, 73, 78, 94, 108].

Six other less frequently mentioned themes were linked to this TDF domain (Table 4).

\section{Intentions-TDF domain no. 8}

Theme: Motivation to work with at-risk drinkers In 2 qualitative studies from Australia and the UK, GPs acknowledged they were not interested in dealing with alcohol problems $[105,107]$. The majority of the GPs in 8 from a total of 10 quantitative studies felt unmotivated to work with at-risk drinkers $[16,23,44,57,62,66,78$, $94,95,108]$. In 1 survey study from Sweden, nurses scored neutral on a motivational scale from 1 to 7 [20]. The majority of the GPs from several countries [47, 59, 60,67 , and of the nurses in 1 UK-based study [59], reported that more training in brief interventions would increase their motivation to work with at-risk drinkers. Seventeen to $33 \%$ of the GPs from Sri Lanka and the UK agreed they would be more willing to work with at-risk drinkers if financial incentives were provided [59, 67].

Theme: Therapeutic commitment Five quantitative studies (4 on GPs and 1 in both GPs and nurses) employed a validated scale for measuring GPs' and nurses' predisposition for working therapeutically with at-risk drinkers [45-47, 50, 81]. All 5 studies reported that the majority of these professionals were not therapeutically committed.

\section{Goals-TDF domain no. 9}

Theme: Importance/priority given to alcohol issues Fourteen to $54 \%$ of the GPs in 3 quantitative studies considered alcohol an unimportant issue in PHC [23, 47, 78]. Creating a specific billing code for this area was reported by some Norwegian GPs as a facilitator to increase GPs awareness of the importance of alcoholrelated problems [99].

Theme: Time Alcohol was not a goal priority for GPs because they were too busy, which makes them neglect alcohol issues in favour of other presenting problems $[23,47,78,83,92,105,106]$. Implementing a short questionnaire in the registration system [39] and increasing knowledge that a brief intervention costs little time and can be effective [39] were suggested as facilitators.

\section{Reinforcement-TDF domain no. 7}

Theme: Incentives The majority of the GPs in 3 quantitative studies reported that alcohol SBI activities were not reimbursable under government health schemes [47, $78,83]$. Three qualitative studies reported that GPs and nurses would feel incentivized if financial reimbursement for providing alcohol brief interventions was available $[39,80,105]$; however, only $24 \%$ of the GPs and nurses in 2 survey studies from the Nordic countries agreed with this $[20,36]$.

\section{Optimism-TDF domain no. 5}

Theme: Beliefs about the ability to deliver SBI and in helping patients to cut down Two quantitative studies from New Zealand and the UK found that 13 to $28 \%$ of the GPs felt pessimistic about what they could do to help at-risk drinkers [55, 62]. More training for improving counselling skills $[49,78]$ and feedback on successful cases [71] were reported as facilitators.

\section{Opportunity (COM-B component 3 )}

The 17 themes in the opportunity component of the COM-B system, which includes two TDF domains (Environmental context and resources; Social influences), emerged from 66 studies from 25 countries (Table 5). The majority of the studies $(n=33)$ were quantitative in design and reported data mainly from GPs alone $(n=44)$.

\section{Environmental context and resources-TDF domain no. 11}

Theme: Time GPs and nurses often cited time constraints as a barrier for implementing alcohol SBI. For some doctors and nurses, alcohol SBI was too timeconsuming $[72,95,106]$ and they were already too busy dealing with other problems [23, 47, 78, 83, 92, 106]. More time per consultation [39, 70, 80, 92, 97], more experience in delivering brief interventions [93], and simpler screening processes (e.g. short and simple screening tools, giving patients self-report questionnaires) [39] were reported as facilitators.

Theme: Support Data from both qualitative and quantitative studies show that, in general, providers felt they could be working in a more supportive environment for delivering alcohol SBI. The majority of the GPs in 3 survey studies reported lack of support from government health policies [47, 78, 83]. Most GPs in 1 study from South Africa reported difficulties in referring patients for 
Table 5 Themes coded to each of the TDF domains within the opportunity component of the COM-B system

\begin{tabular}{|c|c|c|c|c|}
\hline TDF & Theme & Countries & References on barriers & $\begin{array}{l}\text { References on } \\
\text { facilitators }\end{array}$ \\
\hline \multirow[t]{6}{*}{$\begin{array}{l}\text { Environmental } \\
\text { context and } \\
\text { resources }\end{array}$} & Time & $\begin{array}{l}\text { UK(10); Sweden(7); Australia(5); USA(5); } \\
\text { Finland(2); Multicountry(2); Norway(2); } \\
\text { Slovenia(2); Canada(1); Denmark(1); } \\
\text { Netherlands(1); New Zealand(1); Portugal(1); } \\
\text { South Africa(1); Sri Lanka(1) }\end{array}$ & $\begin{array}{l}{[16,20,23,37,41,47-49,52,54} \\
58-62,65,67,70-74,78,83,87 \\
91-93,95,97,99,103,105-107 \\
109,111,116]\end{array}$ & $\begin{array}{l}{[39,43,70,71,80,92,} \\
93,97]\end{array}$ \\
\hline & Support & $\begin{array}{l}\text { UK(12); Multicountry(4); Canada(3); Finland(3); } \\
\text { New Zealand(2); Norway(2); South Africa(2); } \\
\text { Sweden(2); USA(2); Brazil(1); France(1); Italy(1); } \\
\text { Netherlands(1); Slovenia(1); Sri Lanka(1); }\end{array}$ & $\begin{array}{l}{[46,47,55-57,61,63,65,70,71} \\
75,78,82,83,88,92,96,101,105 \\
108,109,112,114]\end{array}$ & $\begin{array}{l}{[20,23,36,37,39,47} \\
59,60,62,67,70,71,7 \\
81,84,92,97,99,100 \\
105,110]\end{array}$ \\
\hline & Resources & $\begin{array}{l}\text { Finland(4); Sweden(3); UK(3); Australia(2); } \\
\text { Multicountry(2); Canada(1); Netherlands(1); } \\
\text { New Zealand(1); Norway(1); Slovenia(1); South } \\
\text { Africa(1); USA(1) }\end{array}$ & $\begin{array}{l}{[20,23,38,41,42,47,58,63,69} \\
74,78,83,103,109]\end{array}$ & $\begin{array}{l}{[20,23,37,39,42,47} \\
55,70,78,88,92,99]\end{array}$ \\
\hline & $\begin{array}{l}\text { Patients' denial of the } \\
\text { problem and } \\
\text { resistance to } \\
\text { accepting treatment }\end{array}$ & $\begin{array}{l}\text { Australia(2); USA(2); Brazil(1); Canada(1); } \\
\text { France(1); Finland(1); New Zealand(1); } \\
\text { Norway(1); Sweden(1) }\end{array}$ & $\begin{array}{l}{[41,52,56,58,63,65,73,86,97,} \\
112,113]\end{array}$ & \\
\hline & $\begin{array}{l}\text { Patients' feelings } \\
\text { when asked about } \\
\text { their drinking }\end{array}$ & $\begin{array}{l}\text { UK(3); Multicountry(2); USA(2); Australia(1); } \\
\text { France(1); New Zealand(1); Slovenia(1); } \\
\text { Sweden(1) }\end{array}$ & $\begin{array}{l}{[20,23,47,56,71,78,92,97,103,} \\
115]\end{array}$ & {$[58,93]$} \\
\hline & $\begin{array}{l}\text { Organization for } \\
\text { preventive }\end{array}$ & $\begin{array}{l}\text { UK(5); Sweden(4); Slovenia(2); Australia(1); } \\
\text { Canada(1); Finland(1); Multicountry(1); }\end{array}$ & {$[47,52,74,78,83,89,103,109]$} & $\begin{array}{l}{[39,41,54,70,71,73} \\
76,80,91,93,97,99]\end{array}$ \\
\hline
\end{tabular}

counselling Netherlands(1); New Zealand(1); Norway(1); South Africa(1); USA(1)

Incentives for Multicountry(2); UK(2); Canada(1); Italy(1); patients South Africa(1)

Patients' beliefs about Finland(2); UK(2); New Zealand(1) alcohol

Patients with alcohol UK(2); Denmark(1); New Zealand(1)

problems do not

attend their

appointments

Patients'

receptiveness to

alcohol interventions

Delivering SBI can

make other patients

suffer

Familiarity with the

patient

Social support Patients' feelings when asked about their drinking

Patients' reactions when asked about alcohol

Doctors' and nurses' permissiveness towards alcohol

Patients seeking help

Support

Patients' receptiveness to

Australia(1): Denmark(1): New Zealand(1): Norway(1); UK(1); USA(1)

Sweden(1); UK(1)

UK(2)

UK(4); Multicountry(2); USA(2); Australia(1); Brazil(1); France(1); New Zealand(1);

Norway(1); Slovenia(1); Sweden(1)

UK(4); Sweden(3); Australia(1); Denmark(1); Finland(1); Multicountry(1); Norway(1)

UK(2); Finland(1); Multicountry(1); Sweden(1); USA(1)

Finland(2); Multicountry(2); UK(2); Brazil(1); France(1)

UK(8); Multicountry(3); Finland(2); Norway(2); Slovenia(2); Sweden(2); Italy(1); Netherlands(1); New Zealand(1); Sri Lanka(1)

Australia(1); Denmark(1); New Zealand(1);

alcohol interventions
Norway(1); UK(1); USA(1)
$[58,87,97]$

$[73,95]$

[105]

[71]

$[20,23,47,56,71,78,88,92,93, \quad[58,93]$ $97,99,103,113,115]$

$[49,70,73,84,86,89,92,95,102$, $105]$

$[20,23,41,47,89,115]$

$[41,42,56,113]$

$[23,41,47,78,92]$

$[82,99,103]$

$[20,23,36,37,39,47$, $59,62,67,70,71,78,80$ $84,92,97,99,100,105$, 110]

$[58,87,97]$ 
Table 5 Themes coded to each of the TDF domains within the opportunity component of the COM-B system (Continued)

\begin{tabular}{|c|c|c|c|c|}
\hline TDF & Theme & Countries & References on barriers & $\begin{array}{l}\text { References on } \\
\text { facilitators }\end{array}$ \\
\hline & Role legitimacy & Norway(1); USA(1) & {$[99,115]$} & \\
\hline & $\begin{array}{l}\text { Presence of third } \\
\text { parties in the } \\
\text { consultation }\end{array}$ & New Zealand(1) & [97] & \\
\hline
\end{tabular}

specialized services [114]; however, this was not an issue for the majority of the GPs from Canada and Sweden $[70,112]$. Only $35 \%$ of the GPs in 1 UK-based study agreed that there is adequate support for GPs from specialized alcohol services [61]. Better co-operation with specialized services $[20,39,59,60,80]$, involving other professionals in general practice (e.g. an addiction consultant or a specialized nurse) $[39,71,105]$, public health educational campaigns $[23,47,78,99,110]$ and more media attention $[39,110]$ were among the most commonly cited facilitators.

Theme: Resources GPs from several countries reported lack of resources for implementing alcohol SBI. Lack of resources included lack of screening tools $[20,23,47,74$, $78]$, counselling materials [20, 23, 42, 47, 78, 109] and specific guidelines [103]. Having these resources and displaying information in the waiting room (e.g. posters) were reported as facilitators in several studies $[20,23$, $37,39,47,55,78,92]$.

Nine other less frequently mentioned themes were linked to this TDF domain (Table 5).

\section{Social influences-TDF domain no. 12}

Theme: Patients' feelings when asked about their drinking Both GPs and nurses in 6 qualitative studies expressed their concern about negative reactions from patients when discussing alcohol issues $[49,84,86,89$, $92,105]$. However, the majority of both doctors and nurses mentioned that this is the exception rather than the rule in 3 out of 4 studies [70, 73, 95, 102]. Experience with SBI could act as a facilitator.

Theme: Doctors' and nurses' permissiveness towards alcohol Some GPs recognized that they have liberal attitudes towards alcohol. In 1 qualitative study from Finland it was pointed out that GPs are members of the community and that it is only natural that they have the same attitudes towards alcohol as their patients [41]. In 2 qualitative studies from the UK and the USA, nurses reported that societal acceptance of heavy drinking can make them hesitate to assess for alcohol in their patients $[89,115]$.

Six other less frequently mentioned themes were linked to this TDF domain (Table 5).

\section{Discussion}

This review identified a range of barriers and facilitators influencing GPs' and primary care nurses' routine delivery of alcohol SBI in adults that linked to the capability, opportunity and motivation components of the COM-B system and to all TDF domains.

The analysis linked all the TDF domains within each component of the COM-B system to at least one of the barriers identified. This suggests that increasing all aspects of capability, opportunity and motivation may be needed for successfully implementing alcohol SBI in primary health care. Furthermore, several barriers linked to more than one TDF domain suggesting that multicomponent strategies may be needed to address some barriers. For example, 'time' linked to the TDF domains 'environmental context and resources' and 'beliefs about capabilities'. Restructuring the environment (e.g. involving receptionists in the screening process, arranging for more time per consultation) and modelling (e.g. demonstrating that advising at-risk drinkers within the time of the consultation is manageable) are examples of strategies that could be used to address this barrier. These findings highlight the challenges researchers face in studying alcohol SBI implementation in PHC and help to understand why routine delivery of alcohol SBI in PHC has been proven difficult to implement.

The analysis identified the following TDF domains as having the highest number of data units coded: 'Environmental Context and Resources'; 'Beliefs about Capabilities'; and 'Skills'. Comparatively, few data units were linked to 'Behaviour Control', 'Memory, Attention and Decision Processes' and 'Optimism'. Caution should be exerted when deciding the domains on which to intervene based on the frequency a particular barrier is reported in the literature. The behaviour change theories most commonly used in research to explain healthcare professionals' behaviours are based on constructs related to the reflective, rather than the automatic, aspect of behaviour, which could lead to a bias in the frequency of the reported factors to behaviour change [117]. For example, the majority of studies found in this review are survey-based which provided GPs and nurses with a list of potential barriers, potentially inflating the salience of those barriers whilst neglecting others that could explain the variance of the behaviour. Therefore, it is conceivable that significant barriers to implementation linked to 
TDF domains with fewer data units coded are yet to be identified, which could give the misleading idea that addressing these domains are less likely to influence implementation. Huijg and colleagues developed a TDF-based questionnaire [118] that could be tailored to study these under-explored barriers and assess their importance.

In a previous review, Johnson and colleagues identified barriers and facilitators to implementing alcohol screening and brief interventions [27]. This review included studies from settings other than PHC, reported only on studies published in English, and gave priority to studies judged most likely to inform UK practice. Our review updates the Johnson et al. review concerning the barriers and facilitators to implementation in PHC. Firstly, we provide evidence on barriers and facilitators from several countries that were not limited to inform a particular practice. One recently published survey study conducted in the largest five European Union countries found that the most frequently cited barriers to implementing alcohol screening among patients with hypertension varied substantially from country to country [119]. This shows that the barriers to, and facilitators of, implementation can vary substantially, between countries that are in geographic proximity and even from place to place within countries. Country features such as individually paid vs nationally funded healthcare, educational level and buying power could influence the salience of a particular factor in the implementation efforts. Therefore, the successful implementation of alcohol SBI will be contingent to tailoring the intervention to local needs [120]. By providing a breakdown by country of study, this review could be of use in the selection of the barriers and facilitators that are more meaningful locally. Secondly, this review was informed by a theoretical framework of behaviour change. Most programmes in practice and research have lacked a theoretical rationale for how they would change practitioner behaviour [28, 121, 122]. Understanding how identified barriers and facilitators fit with the theoretical understandings of behaviour change are key to inform intervention design, and may increase the chances of successful implementation. For example, we have used the results of this review to inform the design of a novel practitioner intervention which has been trialed in Portugal [123]. Therefore, this review may also support researchers in the design of novel theory-based interventions.

\section{Implications for the implementation of alcohol SBI}

Notwithstanding the above-mentioned requirement to tailor the intervention to local needs, mapping the barriers to the components of the COM-B system and domains of the TDF framework allowed for the identification of several content themes that may prove useful in the design of future interventions. Therefore, four key recommendations are suggested based on the results of this review:

\section{To develop training programmes for PHC staff}

Both GPs and nurses identified lack of knowledge and skills as hindering factors for the routine delivery of alcohol SBI. Examples of issues that need to be considered in training programmes include the following: lack of familiarity with risky drinking guidelines, difficulties in defining low-risk drinking limits, difficulties in differentiating between harmful drinking and alcohol dependence, not knowing how to identify asymptomatic at-risk drinkers, unawareness of standardized screening tools and not knowing how to deliver a brief intervention are. Training could also be designed to address providers' motivational issues such as lack of confidence in their ability to deliver alcohol SBI, low self-efficacy, believing that patients would resent being asked about alcohol and lack of time;

2. To improve practice organization for preventive counselling

Several GPs reported that PHC practices lack systematic strategies for identifying and advising at-risk drinkers. Strategies for improving practice organization could include involving receptionists in the screening process, having nurses screening for and/or advising atrisk drinkers, and having simple to use screening tools implemented in frequently used questionnaires or registration systems;

3. To provide PHC practices with materials for delivering SBI

GPs commonly reported that a lack of materials for delivering alcohol SBI is an important barrier. Providing PHC practices with guidelines, screening and advice tools and other materials for patients (e.g. posters to display in the waiting room, self-help booklets) are examples of enabling factors to routine alcohol SBI delivery;

\section{To involve key stakeholders in the implementation} process

Many GPs and nurses reported they were not working in a supportive environment for SBI delivery. Involving PHC management, policy makers, specialized health services, media and available community resources could be key for a successful implementation of alcohol SBI in practice.

\section{Recommendations for future research}

The majority of the studies reported GPs views towards the implementation of alcohol SBI. The views of the nurses are less well studied, although they are regarded 
as an underutilized resource for implementing alcohol SBI. Future primary research could endeavour to better characterize the barriers and facilitators nurses face when implementing alcohol SBI in PHC.

The majority of the studies retrieved pertain to highincome countries which means that the results of this review may not be representative of barriers and facilitators in lower-income countries.

\section{Strengths and limitations}

The inclusion of both quantitative and qualitative studies from the onset of literature is a strength of this review as it provides a comprehensive understanding of the factors that influence the implementation of alcohol SBI in PHC. This does not mean that all barriers and facilitators will be relevant to all settings; implementation researchers should consider and consult on what makes sense locally. Another strength of this review is that no limitation was applied to the countries in which the study was conducted and a breakdown by country is provided. This allows researchers to directly use data from their own countries and/or to use data from countries they judge to be meaningful locally. A final strength of this review is that it was informed by a theoretical framework to guide the understanding of the barriers and facilitators. We were able to link all extracted data to the components of the COM-B system and TDF domains, providing a well-established structure to support the design of interventions for implementing alcohol SBI in PHC.

A limitation of this review is that it identified barriers and facilitators from the perspective of GPs and nurses only. GPs and nurses often cited the need to involve other PHC staff (e.g. receptionists) in the implementation efforts. Hence, knowing the views of other PHC professionals, management and patients could have been important for a thorough understanding of the factors influencing implementation. This review was limited to studies published in English, French, Portuguese and Spanish: the results do not capture factors from studies which may be published in other languages. We have not taken into account the quality of the studies included in the review whilst synthesizing the findings. However, we report our appraisal of the quality of each study (Table 1) to assist the reader in interpreting the findings. Finally, we limited our search to four databases. Other factors may emerge from searching in other databases and grey literature.

\section{Conclusion}

This study identified a wide range of potential barriers and facilitators to the implementation of alcohol SBI delivery in primary care practices and adds to the scarce body of literature that identifies the barriers and facilitators from a theoretical perspective. Given that alcohol SBI is seldom implemented, this review provides researchers with a tool for designing novel theory-oriented interventions to support the implementation of such activity.

\section{Supplementary Information}

The online version contains supplementary material available at https://doi. org/10.1186/s13012-020-01073-0.

Additional file 1. PRISMA 2009 Checklist. This file provides a completed version of the PRISMA Checklist

Additional file 2. Electronic search strategy for the retrieval of studies from multiple databases. This file details the search strategy employed in the review.

Additional file 3. List of unobtainable full-text papers. This file details the articles that were selected for full-text analysis but that were not possible to obtain.

Additional file 4. Excluded full-text articles and references. This file details the articles that were excluded after full-text analysis.

Additional file 5. Title of data: Themes of barriers within each of the components of the COM-B system and domains of the Theoretical Domains Framework. This file details the barriers extracted after full-text analysis.

Additional file 6. Facilitators linked to the identified themes of barriers. This file details the facilitators extracted after full-text analysis.

\section{Abbreviations}

BCW: Behaviour change wheel; COM-B: Capability-Opportunity-MotivationBehaviour; GPS: General practitioners; PHC: Primary health care; SBI: Screening and brief interventions; TDF: Theoretical Domains Framework

\section{Acknowledgements}

Not applicable.

Authors' contributions

FR contributed to the study design, all data collection, coding and synthesis, and the drafting of the manuscript. MIS contributed to all data collection, coding and synthesis and reviewing the manuscript. KA assisted with the conception of the search strategy, performed the search on the databases and reviewed the manuscript. LP contributed to the study design, quality assessment of the included studies, and reviewed the manuscript. CR contributed by reviewing the manuscript. NF contributed to the study design, editing and reviewing the manuscript. The authors read and approved the final manuscript.

\section{Funding}

Not applicable.

\section{Availability of data and materials}

All data generated or analysed during this study are included in this published article (and its supplementary information files).

Ethics approval and consent to participate Not applicable.

Consent for publication

Not applicable.

\section{Competing interests}

The authors declare that they have no competing interests.

\section{Author details}

${ }^{1}$ Instituto de Medicina Preventiva e Saúde Pública, Faculty of Medicine, Lisbon University, Avenida Professor Egas Moniz, 1649-028 Lisbon, Portugal. 
${ }^{2}$ Agrupamento de Centros de Saúde Dão Lafões, Av. António José de Almeida - Edíficio MAS, 3514-511 Viseu, Portugal. ${ }^{3}$ Hospital Casa de Saúde São Mateus SA, Rua 5 de Outubro 183, 3500-093 Viseu, Portugal. ${ }^{4}$ Institute for Social Marketing \& Health (ISMH), Faculty of Health Sciences \& Sport, University of Stirling, Stirling FK9 4LA, Scotland, UK. ${ }^{5}$ Academic Centre for General Practice, KU Leuven, Kapucijnenvoer 33 blok j - box 7001, 3000 Leuven, Belgium.

\section{Received: 7 March 2020 Accepted: 10 December 2020} Published online: 07 January 2021

\section{References}

1. Lim SS, Vos T, Flaxman AD, et al. A comparative risk assessment of burden of disease and injury attributable to 67 risk factors and risk factor clusters in 21 regions, 1990-2010: a systematic analysis for the Global Burden of Disease Study 2010. Lancet. 2012;380:2224-60.

2. WHO. Global status report on alcohol and health 2018. Geneva: World Health Organization; 2018. Licence: CC BY-NC-SA 3.0 IGO. http://apps.who. int/iris/bitstream/handle/10665/274603/9789241565639-eng.pdf?ua=1. Accessed 16 Oct 2018

3. Patel V, Chisholm D, Parikh R, et al. Addressing the burden of mental, neurological, and substance use disorders: key messages from Disease Control Priorities, 3rd edition. Lancet. 2016;387:1672-85.

4. Rehm J, Gmel G, Probst C, Shield KD. Lifetime-risk of alcohol-attributable mortality based on different levels of alcohol consumption in seven European countries. Implications for low-risk drinking guidelines. Toronto: Centre for Addiction and Mental Health; 2015. https://www.camh.ca/en/ research/news_and_publications/reports_and_books/Documents/ Lifetime\%20Risk\%20of\%20Alcohol-Attributable\%20Mortality.pdf. Accessed 22 Mar 2017.

5. The SAFER iniciative. World Health Organization. http://www.who.int/ substance_abuse/safer/launch/en/. Accessed 16 Oct 2018.

6. Angus C, Thomas C, Anderson P, Meier PS, Brennan A. Estimating the costeffectiveness of brief interventions for heavy drinking in primary health care across Europe. Eur J Public Health. 2017;27:345-51.

7. Ballesteros J, Duffy JC, Querejeta I, Arino J, Gonzalez-Pinto A. Efficacy of brief interventions for hazardous drinkers in primary care: systematic review and meta-analyses. Alcohol Clin Exp Res. 2004;28:608-18.

8. Bertholet N, Daeppen JB, Wietlisbach V, Fleming M, Burnand B. Reduction of alcohol consumption by brief alcohol intervention in primary care: systematic review and meta-analysis. Arch Intern Med. 2005;165:986-95.

9. Cuijpers $P$, Riper $H$, Lemmers $L$. The effects on mortality of brief interventions for problem drinking: a meta-analysis. Addiction. 2004;99: 839-45

10. Gordon L, Graves N, Hawkes A, Eakin E. A review of the cost-effectiveness of face-to-face behavioural interventions for smoking, physical activity, diet and alcohol. Chronic IIIn. 2007;3:101-29.

11. Kaner EF, Beyer FR, Muirhead C, et al. Effectiveness of brief alcohol interventions in primary care populations. Cochrane Database Syst Rev. 2018;2:CD004148.

12. Purshouse RC, Brennan A, Rafia R, et al. Modelling the cost-effectiveness of alcohol screening and brief interventions in primary care in England. Alcohol Alcohol. 2013;48:180-8.

13. Solberg LI, Maciosek MV, Edwards NM. Primary care intervention to reduce alcohol misuse ranking its health impact and cost effectiveness. Am J Prev Med. 2008:34:143-52.

14. Bulc M, Svab I, Godycki-Cwirko M. Factors that affect readiness to change lifestyle: a 22-country survey from primary care. Eur J Gen Pract. 2015:21:33-8.

15. Hoertel N, Crochard A, Rouillon F, Limosin F. Patterns of alcohol consumption in France and their medical and social consequences as seen through the family circle and friends and general practitioners. L'Encephale. 2014:40 Suppl 1:S11-31.

16. Ribeiro C. Family medicine approach to alcohol consumption: detection and brief interventions in primary health care. Acta Med Port. 2011;24 Supp 2:355-68.

17. Wolstenholme A, Drummond C, Deluca P, et al. Alcohol interventions and treatment in Europe. In: Anderson P, Braddick F, Reynolds J, Gual A, editors. Alcohol Policy in Europe: Evidence from AMPHORA. The AMPHORA Project; 2012. https://serval.unil.ch/resource/serval:BIB 744F4E07AB5E.P001/REF.pdf. Accessed 03 Aug 2020.
18. Brown J, West R, Angus $C$, et al. Comparison of brief interventions in primary care on smoking and excessive alcohol consumption: a population survey in England. Br J Gen Pract. 2016;66:e1-9.

19. Cheeta S, Drummond C, Oyefeso A, et al. Low identification of alcohol use disorders in general practice in England. Addiction. 2008;103:766-73.

20. Geirsson M, Bendtsen P, Spak F. Attitudes of Swedish general practitioners and nurses to working with lifestyle change, with special reference to alcohol consumption. Alcohol Alcohol. 2005;40:388-93.

21. Hilbink M, Voerman G, van Beurden I, Penninx B, Laurant M. A randomized controlled trial of a tailored primary care program to reverse excessive alcohol consumption. J Am Board Fam Med. 2012;25:712-22.

22. Roche AM, Richard GP. Doctors' willingness to intervene in patients' drug and alcohol problems. Soc Sci Med. 1991;33:1053-61.

23. Wilson GB, Lock CA, Heather N, Cassidy P, Christie MM, Kaner EF. Intervention against excessive alcohol consumption in primary health care: a survey of GPs' attitudes and practices in England 10 years on. Alcohol Alcohol. 2011;46:570-7.

24. Anderson P, Bendtsen P, Spak F, et al. Improving the delivery of brief interventions for heavy drinking in primary health care: outcome results of the Optimizing Delivery of Health Care Intervention (ODHIN) five-country cluster randomized factorial trial. Addiction. 2016;111:1935-45.

25. Glass JE, Andreasson S, Bradley KA, et al. Rethinking alcohol interventions in health care: a thematic meeting of the International Network on Brief Interventions for Alcohol \& Other Drugs (INEBRIA). Addict Sci Clin Pract. 2017;12:14.

26. McCambridge J, Saitz R. Rethinking brief interventions for alcohol in general practice. BMJ. 2017;356:j116.

27. Johnson M, Jackson R, Guillaume L, Meier P, Goyder E. Barriers and facilitators to implementing screening and brief intervention for alcohol misuse: a systematic review of qualitative evidence. J Public Health (Oxf) 2010:33:412-21.

28. Michie S, Prestwich A. Are interventions theory-based? Development of a theory coding scheme. Health Psychol. 2010;29:1-8.

29. Michie S, van Stralen MM, West R. The behaviour change wheel: a new method for characterising and designing behaviour change interventions. Implement Sci. 2011;6:42.

30. Cane J, O'Connor D, Michie S. Validation of the theoretical domains framework for use in behaviour change and implementation research. Implement Sci. 2012;7:37.

31. Moher D, Liberati A, Tetzlaff J, Altman DG, Group P. Preferred reporting items for systematic reviews and meta-analyses: the PRISMA statement. BMJ. 2009;339:b2535.

32. Rosário F, Santos M, Angus K, Pas L, Ribeiro C, Fitzgerald N. Factors Influencing the Implementation of Screening and Brief Interventions for Alcohol Use in Primary Care Practices: A Systematic Review Protocol. Acta Med Port. 2018;31:45-50 Erratum-ibid 2018;31(2):139.

33. Study Quality Assessment Tools. National Heart, Lung and Blood Institute. 2014. https://www.nhlbi.nih.gov/health-pro/guidelines/in-develop/ cardiovascular-risk-reduction/tools. Accessed 31 May 2017.

34. CASP Checklists. Critical Appraisal Skills Programme (CASP). 2017. http:// www.casp-uk.net/casp-tools-checklists. Accessed 31 May 2017.

35. Hannes K. Chapter 4: Critical appraisal of qualitative research. In: Noyes J, Booth A, Hannes K, Harden A, Harris J, Lewin S, Lockwood C, editors. Supplementary Guidance for Inclusion of Qualitative Research in Cochrane Systematic Reviews of Interventions. Version 1 (updated August 2011). Cochrane Collaboration Qualitative Methods Group; 2011. http://carmg. cochrane.org/supplemental-handbook-guidance. Accessed 02 Aug 2017

36. Aalto M, Pekuri $P$, Seppa K. Primary health care nurses' and physicians' attitudes, knowledge and beliefs regarding brief intervention for heavy drinkers. Addiction. 2001;96:305-11.

37. Aalto M, Pekuri P, Seppa K. Obstacles to carrying out brief intervention for heavy drinkers in primary health care: a focus group study. Drug Alcohol Rev. 2003a;22:169-73.

38. Aalto M, Varre T, Pekuri P, Seppa K. The role of general practitioners' working style and brief alcohol intervention activity. Addiction. 2003;98:1447-51.

39. Abidi L, Oenema A, Nilsen P, Anderson P, van de Mheen D. Strategies to Overcome Barriers to Implementation of Alcohol Screening and Brief Intervention in General Practice: a Delphi Study Among Healthcare Professionals and Addiction Prevention Experts. Prev Sci. 2016;17:689-99.

40. Abouyanni G, Stevens L, Harris M, et al. GP attitudes to managing drug- and alcohol-dependent patients: a reluctant role. Drug Alcohol Rev. 2000;19: 165-70. 
41. Aira M, Kauhanen J, Larivaara P, Rautio P. Factors influencing inquiry about patients' alcohol consumption by primary health care physicians: qualitative semi-structured interview study. Fam Pract. 2003;20:270-5.

42. Aira M, Kauhanen J, Larivaara P, Rautio P. Differences in brief interventions on excessive drinking and smoking by primary care physicians: qualitative study. Prev Med. 2004:38:473-8.

43. Ampt AJ, Amoroso C, Harris MF, McKenzie SH, Rose VK, Taggart JR. Attitudes, norms and controls influencing lifestyle risk factor management in general practice. BMC Fam Pract. 2009;10:59.

44. Anderson P. Managing alcohol problems in general practice. Br Med J. 1985; 290:1873-5.

45. Anderson P, Kaner E, Wutzke S, et al. Attitudes and managing alcohol problems in general practice: an interaction analysis based on findings from a WHO collaborative study. Alcohol Alcohol. 2004;39:351-6.

46. Anderson P, Kaner E, Wutzke S, et al. Attitudes and management of alcohol problems in general practice: descriptive analysis based on findings of a World Health Organization international collaborative survey. Alcohol Alcohol. 2003;38:597-601.

47. Anderson P, Wojnar $M$, Jakubczyk A, et al. Managing alcohol problems in general practice in Europe: results from the European ODHIN survey of general practitioners. Alcohol Alcohol. 2014;49:531-9.

48. Arborelius E, Damstrom TK. Why is it so difficult for general practitioners to discuss alcohol with patients? Fam Pract. 1995;12:419-22.

49. Beich A, Gannik D, Malterud K. Screening and brief intervention for excessive alcohol use: qualitative interview study of the experiences of general practitioners. BMJ. 2002;325:870

50. Bendtsen P, Anderson P, Wojnar M, et al. Professional's Attitudes Do Not Influence Screening and Brief Interventions Rates for Hazardous and Harmful Drinkers: Results from ODHIN Study. Alcohol Alcohol. 2015;50:430-7.

51. Berner MM, Harter $M$, Kriston $L$, et al. Detection and management of alcohol use disorders in German primary care influenced by non-clinical factors. Alcohol Alcohol. 2007:42:308-16.

52. Brennan C, Newton M, Wood F, Schug SA, Allsop S, Browne AL. Training general practitioners in remote Western Australia in a method of screening and brief intervention for harmful alcohol use: a pilot study. Aust J Rural Health. 2013;21:72-9.

53. Brotons C, Bjorkelund C, Bulc M, et al. Prevention and health promotion in clinical practice: the views of general practitioners in Europe. Prev Med. 2005;40:595-601.

54. Carlfjord S, Lindberg M, Andersson A. Staff perceptions of addressing lifestyle in primary health care: a qualitative evaluation 2 years after the introduction of a lifestyle intervention tool. BMC Fam Pract. 2012;13:99.

55. Casswell S, McPherson M. Doctors and alcohol. The responses of a selfselected group of general practitioners to patients with alcohol-related problems. N Z Med J. 1982;95:462-6.

56. Charrel CL, Cuervo-Lombard CV, Miron M, Fruntes V, Bera-Potelle C, Limosin F. Alcohol dependence in women: difficulty of its assessment in general practice. J Womens Health. 2010;19:343-8.

57. Clement $\mathrm{S}$. The identification of alcohol-related problems by general practitioners. Br J Addict. 1986;81:257-64.

58. Clifford A, Shakeshaft A. Evidence-based alcohol screening and brief intervention in Aboriginal Community Controlled Health Services: experiences of health-care providers. Drug Alcohol Rev. 2011;30:55-62.

59. Deehan A, Marshall E, Taylor C, Strang J. Who in the primary health care team can tackle alcohol misuse? J Subst Abus. 1999;4:51-6.

60. Deehan A, Taylor C, Strang J. The general practitioner, the drug misuser, and the alcohol misuser: major differences in general practitioner activity, therapeutic commitment, and 'shared care' proposals. Br J Gen Pract. 1997;47:705-9.

61. Deehan A, Templeton L, Taylor C, Drummond C, Strang J. Low detection rates, negative attitudes and the failure to meet the "Health of the Nation" alcohol targets: findings from a national survey of GPs in England and Wales. Drug Alcohol Rev. 1998;17:249-58.

62. Farmer R, Greenwood N. General Practitioners' Management of Problem Drinkers - attitudes, knowledge and practice. Drugs: Educ Prev Policy. 2001; 8:119-29.

63. Ferguson $L$, Ries R, Russo J. Barriers to identification and treatment of hazardous drinkers as assessed by urban/rural primary care doctors. J Addict Dis. 2003;22:79-90.

64. Fernández E, Martínez F, Jordana M, Moraga A. Actitud de los médicos de atención primaria sobre los pacientes con consumo excesivo de alcohol. Aten Primaria. 1999;24:447-55.
65. Friedmann PD, McCullough D, Chin MH, Saitz R. Screening and intervention for alcohol problems. A national survey of primary care physicians and psychiatrists. J Gen Intern Med. 2000;15:84-91.

66. Fucito L, Gomes B, Murnion B, Haber P. General practitioners' diagnostic skills and referral practices in managing patients with drug and alcoholrelated health problems: implications for medical training and education programmes. Drug Alcohol Rev. 2003;22:417-24.

67. Gurugama NP, Seneviratne SL, Peiris DT, de Silva HJ. Detection and management of alcohol misuse by general practitioners. Ceylon Med J. 2003:48:122-4.

68. Haley N, Maheux B, Rivard M, Gervais A. Lifestyle health risk assessment. Do recently trained family physicians do it better? Can Fam Physician. 2000;46: 1609-16.

69. Harris MF, Hobbs C, Powell Davies G, Simpson S, Bernard D, Stubbs A. Implementation of a SNAP intervention in two divisions of general practice: a feasibility study. Med J Aust. 2005;183:S54-8.

70. Holmqvist M, Bendtsen P, Spak F, Rommelsjo A, Geirsson M, Nilsen P. Asking patients about their drinking. A national survey among primary health care physicians and nurses in Sweden. Addict Behav. 2008;33:301-14.

71. Hutchings D, Cassidy P, Dallolio E, Pearson P, Heather N, Kaner E. Implementing screening and brief alcohol interventions in primary care: views from both sides of the consultation. Prim Health Care Res Dev. 2006; 7:221-9.

72. Johansson K, Akerlind I, Bendtsen P. Under what circumstances are nurses willing to engage in brief alcohol interventions? A qualitative study from primary care in Sweden. Addict Behav. 2005;30:1049-53.

73. Johansson K, Bendtsen P, Akerlind I. Early intervention for problem drinkers: readiness to participate among general practitioners and nurses in Swedish primary health care. Alcohol Alcohol. 2002;37:38-42.

74. Johansson K, Bendtsen P, Akerlind I. Factors influencing GPs' decisions regarding screening for high alcohol consumption: a focus group study in Swedish primary care. Public Health. 2005a;119:781-8.

75. Kaariainen J, Sillanaukee P, Poutanen P, Seppa K. Opinions on alcoholrelated issues among professionals in primary, occupational, and specialized health care. Alcohol Alcohol. 2001;36:141-6.

76. Kaner $E_{1}$ Lock $C$, Heather N, McNamee $P$, Bond S. Promoting brief alcohol intervention by nurses in primary care: a cluster randomised controlled trial. Patient Educ Couns. 2003:51:277-84.

77. Kaner E, Rapley T, May C. Seeing through the glass darkly? A qualitative exploration of GPs' drinking and their alcohol intervention practices. Fam Pract. 2006;23:481-7.

78. Kaner EF, Heather N, McAvoy BR, Lock CA, Gilvarry E. Intervention for excessive alcohol consumption in primary health care: attitudes and practices of English general practitioners. Alcohol Alcohol. 1999;34:559-66.

79. Kaner EF, Wutzke S, Saunders JB, et al. Impact of alcohol education and training on general practitioners' diagnostic and management skills: findings from a World Health Organization collaborative study. J Stud Alcohol. 2001;62:621-7.

80. Kersnik J, Poplas Susic T, Kolsek M, Svab I. What may stimulate general practitioners to undertake screening and brief intervention for excess alcohol consumption in Slovenia? A focus group study. J Int Med Res. 2009: 37:1561-9.

81. Keurhorst $M$, van Beurden I, Anderson $P$, et al. GPs' role security and therapeutic commitment in managing alcohol problems: a randomised controlled trial of a tailored improvement programme. BMC Fam Pract. 2014;15:70.

82. Kolsek M, Struzzo P, Svab I. Qualitative study on community and primary health care involvement on alcohol and tobacco actions in seven European countries. Subst Use Misuse. 2008;43:303-16.

83. Koopman FA, Parry CD, Myers B, Reagon G. Addressing alcohol problems in primary care settings: a study of general medical practitioners in Cape Town, South Africa. Scand J Public Health. 2008;36:298-302.

84. Lacey J. Alcohol brief interventions: exploring perceptions and training needs. Commun Pract. 2009:82:30-3.

85. Lambe B, Connolly C, McEvoy R. The determinants of lifestyle counselling among practice nurses in Ireland. Int J Health Promotion Educ. 2008;46:94-9.

86. Lid TG, Malterud K. General practitioners' strategies to identify alcohol problems: a focus group study. Scand J Prim Health Care. 2012:30:64-9.

87. Lid TG, Nesvag S, Meland E. When general practitioners talk about alcohol: exploring facilitating and hampering factors for pragmatic case finding. Scand J Public Health. 2015;43:153-8. 
88. Linke S, Harrison R, Wallace P. A Web-based intervention used in general practice for people with excessive alcohol consumption. J Telemed Telecare. 2005;11(Suppl 1):39-41.

89. Lock CA, Kaner E, Lamont S, Bond S. A qualitative study of nurses' attitudes and practices regarding brief alcohol intervention in primary health care. J Adv Nurs. 2002:39:333-42.

90. Maheux B, Haley N, Rivard M, Gervais A. Do physicians assess lifestyle health risks during general medical examinations? A survey of general practitioners and obstetrician-gynecologists in Quebec. CMAJ Can Med Assoc J= journal de l'Association medicale canadienne. 1999:160:1830-4

91. May C, Rapley T, Kaner E. Clinical reasoning, clinical trials and risky drinkers in everyday primary care: A qualitative study of British general practitioners. Addict Res Theory. 2006;14:387-97.

92. McAvoy B, Donovan R, Jalleh G, et al. General Practitioners, Prevention and Alcohol - a powerful cocktail? Facilitators and inhibitors of practising preventive medicine in general and early intervention for alcohol in particular: a 12-nation key informant and general practitioner study. Drugs: Educ Prev Policy. 2001;8:103-17.

93. Miller PM, Stockdell $R$, Nemeth $L$, et al. Initial steps taken by nine primary care practices to implement alcohol screening guidelines with hypertensive patients: the AA-TRIP project. Subst Abus. 2006;27:61-70.

94. Miner M, Giner J, Lacalle J, Franco D, Velasco A. The Detection of Alcoholrelated Problems in Primary Health Care. Gac Sanit. 1990;4:135-9.

95. Mistral W, Velleman R. Substance-misusing patients in primary care: incidence, services provided and problems. A survey of general practitioners in Wiltshire. Drugs: Education. Prev Policy. 2001;8:61-72.

96. Moretti-Pires RO, Ferro SB, Buchele F, de Oliveira HM, Goncalves MJ. Family health nurse in the Amazon: concepts and management of themes regarding alcohol use. Rev Esc Enferm USP. 2011;45:926-32.

97. Mules T, Taylor J, Price R, et al. Addressing patient alcohol use: a view from general practice. J Prim Health Care. 2012;4:217-22

98. Nevin AC, Parshuram C, Nulman I, Koren G, Einarson A. A survey of physicians knowledge regarding awareness of maternal alcohol use and the diagnosis of FAS. BMC Fam Pract. 2002;3:2.

99. Nygaard P, Aasland OG. Barriers to implementing screening and brief interventions in general practice: findings from a qualitative study in Norway. Alcohol Alcohol. 2011;46:52-60.

100. Nygaard P, Paschall MJ, Aasland OG, Lund KE. Use and barriers to use of screening and brief interventions for alcohol problems among Norwegian general practitioners. Alcohol Alcohol. 2010;45:207-12.

101. Owens L, Gilmore IT, Pirmohamed M. General practice nurses' knowledge of alcohol use and misuse: a questionnaire survey. Alcohol Alcohol. 2000;35: 259-62.

102. Payne J, Elliott E, D'Antoine $H$, et al. Health professionals' knowledge, practice and opinions about fetal alcohol syndrome and alcohol consumption in pregnancy. Aust N Z J Public Health. 2005;29:558-64.

103. Poplas Susic T, Kersnik J, Kolsek M. Why do general practitioners not screen and intervene regarding alcohol consumption in Slovenia? A focus group study. Wien Klin Wochenschr. 2010;122(Suppl 2):68-73.

104. Proude EM, Conigrave KM, Haber PS. Effectiveness of skills-based training using the Drink-less package to increase family practitioner confidence in intervening for alcohol use disorders. BMC Med Educ. 2006;6:8.

105. Rapley T, May C, Frances KE. Still a difficult business? Negotiating alcoholrelated problems in general practice consultations. Soc Sci Med. 2006;63: 2418-28.

106. Richmond RL, Mendelsohn CP. Physicians' views of programs incorporating stages of change to reduce smoking and excessive alcohol consumption. Am J Health Promotion. 1998;12:254-7.

107. Roche AM, Guray C, Saunders JB. General practitioners' experiences of patients with drug and alcohol problems. Br J Addict. 1991;86:263-75.

108. Rush B, Bass M, Stewart M, McCracken E, Labreque M, Bondy S. Detecting, preventing, and managing patients' alcohol problems. Can Fam Physician. 1994:40:1557-66.

109. Rush BR, Powell LY, Crowe TG, Ellis K. Early intervention for alcohol use: family physicians' motivations and perceived barriers. CMAJ Can Med Assoc J= journal de l'Association medicale canadienne. 1995;152:863-9.

110. Segnan N, Battista RN, Rosso S, Ponti A, Senore C, Aimar D. Preventive practices of general practitioners in Torino, Italy. Am J Prev Med. 1992;8: 333-8.

111. Sharp L, Vacha-Haase T. Physician Attitudes Regarding Alcohol Use Screening in Older Adult Patients. J Appl Gerontol. 2011;30:226-40.
112. Slaunwhite AK, Macdonald S. Alcohol, Isolation, and Access to Treatment: Family Physician Experiences of Alcohol Consumption and Access to Health Care in Rural British Columbia. J Rural Health. 2015;31:335-45.

113. Souza L, Pinto M. The care of alcohol and other drug users by Family Health nurses. Rev Eletr Enf. 2012;14:374-83.

114. Van Zyl P, Gagiano C, Mollentze W, Snyman J, Joubert G. The role of private general practitioners in the treatment of alcohol dependence in the Free State province. S Afr Fam Pract. 2013;55:561-6.

115. Vandermause R. Assessing for Alcohol Use Disorders in Women: Experiences of Advanced Practice Nurses in Primary Care Settings. J Addictions Nurs. 2007;18:187-98.

116. Vinson DC, Galliher JM, Reidinger C, Kappus JA. Comfortably engaging: which approach to alcohol screening should we use? Ann Fam Med. 2004; 2:398-404.

117. Potthoff S, Presseau J, Sniehotta FF, Johnston M, Elovainio M, Avery L. Planning to be routine: habit as a mediator of the planning-behaviou relationship in healthcare professionals. Implement Sci. 2017;12:24.

118. Huijg JM, Gebhardt WA, Crone MR, Dusseldorp E, Presseau J. Discriminant content validity of a theoretical domains framework questionnaire for use in implementation research. Implement Sci. 2014;9:11.

119. Hanschmidt F, Manthey J, Kraus L, et al. Barriers to Alcohol Screening Among Hypertensive Patients and the Role of Stigma: Lessons for the Implementation of Screening and Brief Interventions in European Primary Care Settings. Alcohol Alcohol. 2017;52:572-9.

120. McCormick R, Docherty B, Segura $L$, et al. The research translation problem: Alcohol screening and brief intervention in primary care - Real world evidence supports theory. Drugs: Educ Prev Policy. 2010;17:732-48.

121. Brehaut JC, Eva KW. Building theories of knowledge translation interventions: use the entire menu of constructs. Implement Sci. 2012;7:114.

122. Davies $P$, Walker AE, Grimshaw JM. A systematic review of the use of theory in the design of guideline dissemination and implementation strategies and interpretation of the results of rigorous evaluations. Implement Sci. 2010;5:14.

123. Rosário F, Vasiljevic M, Pas L, Fitzgerald N, Ribeiro C. Implementing alcohol screening and brief interventions in primary health care: study protocol for a pilot cluster randomized controlled trial. Fam Pract. 2019;36(2):199-205.

\section{Publisher's Note}

Springer Nature remains neutral with regard to jurisdictional claims in published maps and institutional affiliations.

Ready to submit your research? Choose BMC and benefit from:

- fast, convenient online submission

- thorough peer review by experienced researchers in your field

- rapid publication on acceptance

- support for research data, including large and complex data types

- gold Open Access which fosters wider collaboration and increased citations

- maximum visibility for your research: over $100 \mathrm{M}$ website views per year

At $\mathrm{BMC}$, research is always in progress.

Learn more biomedcentral.com/submissions 